\title{
SPECIES OF THE DIATOM GENUS CRATICULA GRUNOW (BACILLARIOPHYCEAE) FROM MACEDONIA
}

\author{
Zlatko Levkov*, Slavica Tofilovska, Danijela Mitić-Kopanja \\ Institute of Biology, Faculty of Natural Sciences and Mathematics, Ss. Cyril and Methodius University, \\ Skopje, Republic of Macedonia \\ *Corresponding author: zlevkov@pmf.ukim.mk
}

\begin{abstract}
The species of the genus Craticula are widely distributed in Europe, mostly occurring in brackish, saline to heavily polluted waters. Some of the species are considered as being most tolerant to pollution. Recently, detailed observations of this genus in Macedonia have been performed. During this study, 15 taxa have been recorded. One of the species (Craticula simplex) was observed with three different morphotypes, which can be distinguished by the valve size and shape. Craticula cuspidata and C. ambigua were the most frequently recorded species in various habitats, while species $C$. halophila, $C$. germainii and $C$. fumantii were observed only on a single locality. The highest diversity of $C$ raticula was observed in temporary ponds on halomorphic soils and mineral springs in Eastern Macedonia.
\end{abstract}

Key words: Craticula; diatoms, diversity, Macedonia

\section{INTRODUCTION}

The genus Craticula Grunow was described based on the species $C$. perrotettii Grunow [1, p. 20, Fig. 1: 21] and was forgotten for a long time until Mann \& Stickle [2] re-established the genus and provided a more detailed description based on ultrastructural and sexual characteristics. Most of the members of this genus were previously included in Navicula Bory section Orthostichae (Cleve [3], Hustedt [4]). One of the prominent features of this genus is the presence of "craticula" - inner valves produced during resting spore formation. Such inner valves might be produced as a result of elevated salt concentrations or desiccation (Schmid $[5,6])$. The inner valves were referred as "heribaudii" valves and they differ by several ultrastructural features from the normal valves. However, "heribaudii" valves are so far observed only in few members of the genus Craticula.

The genus is characterized by cells with two plastids with lenticular pyrenoids that are usually associated with a cytoplasmic bridge holding the nucleus (Cox [7]). The raphe is filiform and can be located externally on thickened conopeum or on valve face (Morales \& Le [8]). Internally the raphe branches are positioned on elevated sternum. The striae are composed of a single row of round or apically elongated areolae. Internally the areolae are covered by hymen. In some species areolae are separated by strongly thickened frets that appear as longitudinal ribs. In most of the species, striae are parallel to weakly radiate in the mid-valve, becoming slightly convergent toward the valve apices.

The genus is widely distributed in various habitats, from acidic oligotrophic waters to alkaline, (hyper)saline, (hyper)eutrophic and heavily polluted waters. Some of the members of the genus are considered as one of the most tolerant species to organic pollution (Lange-Bertalot $[9,10])$. High diversity of the genus was noticed in alkaline, slightly saline and warm (even temporary) water habitats (LangeBertalot [10], Lange-Bertalot et al. [11]). Craticula was observed frequently in the Tropics (Morales et al. 12, Rumrich et al. [13]), but also on Antarctica (Van de Vijver et al. [14]; Sabbe et al. [15]). 
The first records of the genus Craticula in Macedonia originated from Schröder [16] and Hustedt [17] for lakes Dojran and Ohrid with two recorded species: C. ambigua (Ehrenberg) D. G. Mann and C. cuspidata (Kützing) D. G. Mann. Additionally, Hustedt described Navicula demissa [17, p. 928, Fig. 40: 12-15], which was later synonymyzed by Krammer \& Lange-Bertalot [19] with $N$. subminuscula Manguin [18, p. 139, Fig. 2: 39] $\equiv C$. subminuscula (Manguin) C.E. Wetzel \& Ector. Later, two more species $C$. perrotettii (Grunow) D.G. Mann and C. accomoda (Hustedt) D.G. Mann were recorded in Lake Dojran (Stojanov [20]) and the River Vardar (Krstic et al. [21]). Recently, a detailed observation of the diatom flora of Macedonia has been initiated and several genera, including Amphora Ehrenberg (Levkov [22]), Eunotia Ehrenberg (Pavlov \& Levkov [23]), Hippodonta Lange-Bertalot, Metzeltin \& Witkowski (Pavlov et al. [24]), Diploneis Ehrenberg (Jovanovska et al. [25]), Luticola D.G. Mann (Levkov et al. [26]), Odontidium Kützing (Jüttner et al. [27]), Mastogloia Thwaites (Pavlov et al. [28]) and Gomphonema Ehrenberg (Levkov et al. [29]) were observed in more details. This resulted in many new records of the species distribution and additional descriptions of new taxa. Here, we provide a revision of the Craticula species, as a part of an ongoing comprehensive research on the diatom flora of Macedonia.

\section{EXPERIMENTAL SECTION}

More than 6.000 samples observed in this study have been collected during various field campaigns, starting from 1995 until present. Most of the samples were collected within the period June-August. Samples from the various habitats include: sediments at various depths $(0.5-50 \mathrm{~m})$ from Ohrid, Prespa and Dojran lakes, sediments, stones and macrophytes from rivers, small springs, streams and rivulets, high altitude glacial and nonglacial lakes, ponds and pools of various size, peat bogs, fens and mires. The altitudinal range at the different sampling sites varies between ca. 200-2500 $\mathrm{m}$ a.s.l. The samples with higher abundance of Craticula species are listed in Table 1. Diatom samples were cleaned by acid digestion using $\mathrm{K}_{2} \mathrm{MnO}_{4} / \mathrm{HCl}$, and permanent slides were mounted in Naphrax ${ }^{\circledR}$. Photomicrographs were taken with a Nikon E-80i, a digital Nikon Coolpix 600. For scanning electron microscope (SEM) analyses, cleaned material was dried onto aluminum stubs and coated with gold/palladium using a sputter coater. SEM micrographs were produced with a Cambridge Instrument S4 Steroscan electron microscope operated at $5 \mathrm{kV}$. Slides are deposited in the Macedonian National Diatom Collection (MKNDC), Institute of Biology, Skopje, Macedonia (holotype), and the Friedrich Hustedt Centre for Diatom Research (BRM) in Bremerhaven, Germany (isotype).

Table 1. List of observed samples with the highest abundance and diversity of Craticula species

\begin{tabular}{lll}
\hline Acc. No. & Locality & Sample \\
\hline 001133 & Lake Ohrid, the Bay of St. Naum & sediment 9 m depth \\
002212 & Lake Dojran, Alex Beach & plankton \\
003084 & Šara Mountain, Lake Karanikoličko & macrophytes \\
004798 & Lake Dojran, Alex Beach & sediment \\
005603 & Mining Lake Usje & macrophytes \\
006795 & River Bregalnica, before the village of Mačevo & epiphytes on reed \\
006806 & River Bregalnica, before the mouth of river Kočanska & yellow filaments \\
006837 & River Kočanska, before the mouth in R. Bregalnica & brown filaments \\
006967 & Reservoir Ratevsko (Berovsko) & sediment \\
008234 & River Vodenišnica, near Monospitovo & rock scrape \\
008835 & Sveti Nikole, near the village of Adzimatovo, pond & sediment \\
008836 & Sveti Nikole, near the village of Adzimatovo, channel & sediment \\
008838 & Gladno Pole, near Štip, spring, & mud \\
008858 & Mineral spring near the village of Gabrovo, Delčevo & Chara sp. \\
008868 & Slan Dol, temporary pond & mud \\
008872 & Slan Dol, temporary pond & macrophytes \\
008873 & Slan Dol, temporary pond & mud \\
PS001035 & Thermo-mineral spring Negorska Banja & rock scrape \\
\hline
\end{tabular}




\section{RESULTS AND DISCUSSION}

During the observations of the genus Craticula in Macedonia, 13 species in total have been recorded. One of the species, C. simplex (Krasske) Levkov comb. nov. was present with three morphotypes which differ with respect to the valve outline and size. However, we still consider these populations as a part of the morphological variation of a single species. Few valves with similar numerical features as $C$. acidoclinata Lange-Bertalot \& Metzeltin were observed in glacial Lake Karanikoličko on Šara Mountain, but they differ from the type population with respect to the shape of the valve apices.

\section{Craticula perrotettii Grunow}

(Figs 1: 1-3; 2: 1-3)

Valve morphology, LM (Figs 1: 1-3): Valves are lanceolate to broadly-lanceolate with shortly protracted and rounded apices. Valve length varies from $220-244 \mu \mathrm{m}$, and valve width $44-48$ $\mu \mathrm{m}$. Axial area is narrow, linear, widened near the central area. Central area is variable in size and shape, lanceolate to slightly constricted in the middle. Raphe is straight, filiform, positioned on well developed sternum. Proximal raphe endings are expanded into central pores and slightly deflected, while distal endings are hooked and reaching the valve mantle at the apex. Transapical striae are clearly visible with LM, parallel throughout, 11-12 in $10 \mu \mathrm{m}$. Areolae are visible with LM, $16-18$ in 10 $\mu \mathrm{m}$. Areolae are separated by the longitudinal frets.

Valve morphology, SEM (Figs 2: 1-3): Raphe branches are located on strongly thickened conopeum with equal width throughout. Central pores are dilated and slightly unilaterally deflected. Transapical striae are uniseriate composed by areola with variable size and shape. Areolae near the axial and central area have small round apertures, while the rest are apically elongated with slit-like external openings. Longitudinal frets are well developed and forming grooves in which areola are located.

Comment: The conopeum and longitudinal frets present in the specimen from Lake Dojran are narrower and not strongly pronounced as in the specimen depicted in Lange-Bertalot [10, Figs 81: 1-4].

Similar species: In general, $C$. perrotettii has a unique set of characters (valve size, shape and presence of strongly thickened longitudinal frets) that clearly separates it from other Craticula species. Craticula pampeana (Frenguelli) LangeBertalot has similar valve size, but different valve shape, lanceolate with broadly rounded apices
(Frenguelli [30]). Craticula cuspidata has similar valve shape and longitudinal frets, however it can be clearly differentiated by its smaller valves (lenght 82-122 $\mu \mathrm{m}$, width 21.0-27.5 $\mu \mathrm{m}$ ).

Distribution in Macedonia: This species was observed only in Lake Dojran. According to LangeBertalot [10, p. 117] this species is rare in Europe and it was observed only in Southern Italy.

Ecology: Craticula perrotettii occurs in eutrophic to hypereutrophic habitats on organic sediment. This is a tropical/subtropical species preferring habitats with higher temperature [10].

\section{Craticula cuspidata (Kützing) D.G.Mann}

(Figs 3: 1-5; 4: 1-5; 5: 1-5)

Basionym: Frustulia cuspidata Kützing [31, p. 549, Fig. 14: 26]

Nomenclatural synonym: Navicula cuspidata (Kützing) Kützing [32, p. 94]

Valve morphology, LM (Figs 3: 1-5; 4: 15): Valves are broadly lanceolate to rhombiclanceolate, gradually tapering towards apices. Valve apices in larger specimens are shortly protracted and subcapitate to almost acutely rounded in smaller specimens. Valve length varies from $82-$ $122 \mu \mathrm{m}$, valve width $21.0-27.5 \mu \mathrm{m}$. Axial area is very narrow, linear. Central area is absent to narrow lanceolate, slightly wider than axial area. Raphe is straight, filiform. Proximal raphe endings are expanded into central pores and slightly deflected, while distal endings are hooked and reaching the valve mantle at the apex. Transapical striae are clearly visible with LM, parallel throughout, 11-14 in 10 $\mu \mathrm{m}$. Areolae are visible with LM, 26-30 in $10 \mu \mathrm{m}$.

Valve morphology, SEM (Figs 5: 1-5): The valve surface is ornamented with narrow and slightly thickened longitudinal frets (Fig. 5: 4). Raphe is located on a narrow, strongly thickened sternum (Fig. 5: 1). External proximal raphe endings are short, expanded into central pores and slightly unilaterally deflected (Fig. 5: 4). Distally, raphe endings are long, hooked and continuing onto the mantle (Fig. 5: 2). Striae are uniseriate composed of narrow, apically elongated slit-like areolae, except near the central area where areolae have round foramina (Fig. 5: 4). Internally, central nodule is slightly raised (Fig. 5: 5). Raphe branches are straight, located on inwardly elevated sternum. Raphe proximally terminates with short, unilaterally weakly deflected endings, while distally with well developed helictoglossa. Areolae are occluded by hymenes, located inside each areola (Fig. 5: 5).

Similar species: Craticula acidoclinata Lange-Bertalot \& Metzeltin [33, figs 26: 1-3] and 
C. sardiniana Bahls [34, figs 96-101] are similar to C. cuspidata. However, both species have lanceolate valves with broadly rounded apices, opposite to rhombic-lanceolate with shortly protracted or acutely rounded apices in $C$. cuspidata.

Distribution in Macedonia: Craticula cuspidata is frequently recorded taxon in the diatom flora of Macedonia. During this study it was recorded in: lakes: Ohrid, Prespa, Dojran; rivers: Vardar, Lepenec, Bregalnica, Zrnovka, Golema Reka, Anska; reservoirs: Kalimanci and Mladost, stream Jastrebnik on Mt. Osogovo, unnamed streams on mountains Kozuf and Šara, peat-bogs on Karadzica, Šara and Pelister mountains.

Ecology: This species was observed in wide spectrum of habitats: oligotrophic to eutrophic and hyper eutrophic lakes, oligotrophic to mesotrophic rivers, slightly polluted to highly polluted rivers. It occurs on fine inorganic or organic sediments.

\section{Craticula aff. acidoclinata Lange-Bertalot \& Metzeltin (Figs 6: 1-7)}

Valve morphology, LM: Valves are broadly lanceolate gradually tapering towards apices. Valve apices are shortly protracted and rostrate. Valve length varies from 64-91 $\mu \mathrm{m}$, valve width from 17.0-21.0 $\mu \mathrm{m}$. Axial area is very narrow, linear. Central area is absent to narrow lanceolate, slightly wider than axial area. Raphe is straight, filiform. Proximal raphe endings are expanded into central pores and slightly deflected, while distal endings are hooked and reaching the valve mantle at the apex. Transapical striae are clearly visible with LM, parallel throughout, $16-19$ in $10 \mu \mathrm{m}$. Areolae are hardly visible with LM, c. 30 in $10 \mu \mathrm{m}$. Heribaudii stages are frequently observed.

Comment: Craticula aff. acidoclinata resembles C. cuspidata, C. acidoclinata and C. nonambigua Lange-Bertalot, Cavacini, Tagliaventi \& Alfinito. In general, $C$. aff. acidoclinata shares the morphological features of $C$. cuspidata and might represent a smaller form of $C$. cuspidata. However, most of the records of $C$. cuspidata in the available literature show larger cells with width $24-35 \mu \mathrm{m}$ and lower striae density $(11-15$ in $10 \mu \mathrm{m})$ in contrast to $C$. aff. acidoclinata. Also $C$. cuspidata is usually observed in the eutrophic lotic and lentic waters, while the observed taxon in this study $(C$. aff. acidoclinata) was recorded in an oligotrophic, slightly acidic glacial lake. From aspect of the ecology, this species is similar to $C$. acidoclinata. Also, similarities in the morphology can be observed with the specimen depicted in LangeBertalot [10, Fig. 87: 2] from the type population.
However, other illustrated specimens [op.cit., figs 87: 1, 3-5] have completely different valve apices (not protracted and broadly rounded). Similar concept of $C$. acidoclinata (apices are never or only slightly protracted) is presented by Bahls $[34, \mathrm{p}$. 23]. There is difference too in the valve size (17.0$21.0 \mu \mathrm{m}$. vs $24-35 \mu \mathrm{m}$ in C. acidoclinata) and stria density (16-19 in $10 \mu \mathrm{m}$ vs $11-15$ in $10 \mu \mathrm{m}$ in $C$. acidoclinata). Craticula aff. acidoclinata differs from $C$. nonambigua by shape of the valve apices, having weakly protracted apices, opposite to long protracted, rostrate to subcapitate apices in $C$. nonambigua. Additionally, both populations observed in this study have different ecology, cold oligotrophic and slightly acidic ( $C$. aff. acidoclinata) vs dystrophic, alkaline with high mineral content $(C$. nonambigua).

Distribution in Macedonia: This taxon was observed only in glacial Lake Karanikoličko on Šara Mountain.

Ecology: The locality where this taxon was observed represents an oligotrophic lake, circumneutral to slightly acidic, with low mineral content.

\section{Craticula sardiniana Bahls (Figs 7: 1-3)}

Valve morphology, LM: Valves are lanceolate gradually tapering towards apices. Apices weakly protracted and rounded. Valve length varies from 76-93 $\mu \mathrm{m}$ and valve width from 18.5-19.5 $\mu \mathrm{m}$. Axial area is very narrow, linear. Central area is absent to slightly concave. Raphe is straight, filiform. Proximal raphe endings are expanded into central pores and slightly deflected, while distal endings are hooked and reaching the valve mantle at the apex. Transapical striae are parallel in the mid-valve, becoming slightly convergent towards the apices, $13-17$ in $10 \mu \mathrm{m}$. Areolae are hardly visible with LM, 28-32 in $10 \mu \mathrm{m}$.

Comment: According to Lange-Bertalot \& Metzeltin [33, p. 42] C. acidoclinata occurs in oligo-distrophic habitats, while $C$. sardiniana prefers alkaline waters with higher electrolyte content. Craticula sardiniana in Macedonia was observed in a small pond on halomorphic soils near Sveti Nikole, characterized by slightly alkaline $\mathrm{pH}(8.3)$ and high conductivity $\left(1300 \mu \mathrm{S} \bullet \mathrm{cm}^{-1}\right)$.

The differences between $C$. sardiniana from the type population of Bahls [34, figs 96-101], and the population from Macedonia might be noticed in the shape of valve apices. In $C$. sardiniana from the type population, apices are bluntly rounded and not protracted, while the population from the halomorphic soils is characterized by weakly protracted and narrower apices. However, the valve shape of the 
population from Macedonia is similar to the taxon depicted by Lange-Bertalot [10, Figs 88: 1-5] named as Craticula silviae Lange-Bertalot nov. spec. prov. observed in alkaline ephemeral ponds from Sardinia. The conspecificity of these two taxa is questionable. Further studies are necessary to check the identity of C. silviae and its relation with $C$. sardiniana.

Similar species: The most similar species to C. sardiniana is $C$ acidoclinata Lange-Bertalot \& Metzeltin (Lange-Bertalot \& Metzeltin 33, Figs 26: [1-3]). In general morphological and numeral features of $C$. sardiniana and $C$. acidoclinata are overlapping: length $68-113 \mu \mathrm{m} v s$ 60-130 $\mu \mathrm{m}$; width $15.6-19.5 \mu \mathrm{m} v s$ 16.0-24.0 $\mu \mathrm{m}$; stria density 14 in $10 \mu \mathrm{m} v s$ 13-15.5 in $10 \mu \mathrm{m}$. The main difference between these two species is the habitat preference Bahl (2013, p. 23).

Distribution in Macedonia: Craticula sardiniana was observed only from a small, temporary pond on halomorphic soils, Ovche Pole, near the town Sveti Nikole.

Ecology: Craticula sardiniana prefers alkaline, dystrophic waters with high electrolyte content (high conductivity) such as temporary ponds and alkaline ferns.

\section{Craticula ambigua (Ehrenberg) D.G.Mann} (Figs 8: 1-12; 9: 1-5)

Basionym: Navicula ambigua Ehrenberg [35, p. 417, Fig. 2/2: 9]

Nomenclatural synonym: Navicula cuspidata var. ambigua (Ehrenberg) Cleve [36, p. 110]

Valve morphology, LM (Figs 8: 1-12): Valves are broadly elliptic, elliptic-lanceolate to lanceolate to with abruptly protracted and subcapitate apices. Valve margins are with "shoulders" near the valve apices. Valve length varies from 47$77 \mu \mathrm{m}$, valve width $14.5-20.0 \mu \mathrm{m}$. Axial area is very narrow, linear. Central area is absent to slightly wider than axial area. Raphe is straight, filiform. Proximal raphe endings are expanded into central pores and slightly deflected, while distal endings are hooked and reaching the valve mantle at the apex. Transapical striae slightly radiate in the midvalve, becoming slightly convergent towards the apices, $14-17$ in $10 \mu \mathrm{m}$. Areolae are visible with LM, 26-32 in $10 \mu \mathrm{m}$.

Valve morphology, SEM (Figs. 9: 1-5): The valve surface is slightly uneven, ornamented with weakly developed longitudinal frets (Figs. 9: 1-4). Raphe is located on a narrow, strongly thickened sternum, slightly expanded in the central area (Fig. 9: 3). External proximal raphe endings are short, expanded into central pores and slightly uni- laterally deflected (Fig. 9: 3). Distally, raphe endings are long, strongly hooked and continuing onto the mantle (Fig. 9: 4). Striae are uniseriate composed of narrow, apically elongated slit-like areolae, except near the central area where areolae have round foramina (Fig. 9: 3). Internally, central nodule is slightly raised (Fig. 9: 5). Raphe branches are straight, located on inwardly strongly elevated sternum. Raphe proximally terminates with short, simple endings, while distally with well developed helictoglossa. Areolae are covered by hymenes located inside each areola (Fig. 9: 5).

Similar species: Craticula nonambigua Lange-Bertalot, Cavacini, Tagliaventi \& Alfinito, and C. lange-bertalotii E. Reichardt [37, figs 1420] are similar to Craticula ambigua. In general numerical features of $C$. ambigua sensu lato and $C$. nonambigua are overlapping: length $42-77 \mu \mathrm{m} v \mathrm{~s}$ 49-66 $\mu \mathrm{m}$; width 14.5-20.0 $\mu \mathrm{m}$ vs 12.5-18.0 $\mu \mathrm{m}$; stria density $14-17 / 10 \mu \mathrm{m} v s \quad 14-18 / 10 \mu \mathrm{m}$; areola density c. 30 in $10 \mu \mathrm{m}$ vs 30 in $10 \mu \mathrm{m}$. Also significant differences in the valve shape cannot be noticed, except the presence of "shoulders" in C. ambigua. However, in some smaller specimens of $C$. nonambigua (Figs 11: 6-10) indistinct "shoulders" might be noticed too. According to Lange-Bertalot [10], both species can be differentiated by the size and valve outline. In general, both species can be differentiated only by the valve outline (broadly elliptic in $C$. ambigua vs rhombic-lanceolate in $C$. nonambigua) Craticula lange-bertalotii has wider valves $21-25 \mu \mathrm{m}$ with slightly undulated margins and lower areola density $24-26$ in $10 \mu \mathrm{m}$.

Distribution in Macedonia: Lakes: Ohrid, Dojran; rivers: Vardar, Bregalnica, Zrnovka, Zletovska, Svetinikolska, Shamachka, Boshava, Buturica; wetland Studenčiško, mining lake of Usje. The record of $C$. ambigua from Šara Mountain (Levkov et al. [38]) belongs to C. fumantii LangeBertalot, Cavacini, Tagliaventi \& Alfinito. Some older records of C. ambigua (Stojanov [39-41]) might belong to other species.

Ecology: This species was observed in various habitats starting from deep oligotrophic Lake Ohrid, mesotrophic Lake Prespa, the eutrophic River Bregalnica and Lake Dojran. It usually occurs in epipelic diatom assemblages on organic or fine inorganic sediments.

\section{Craticula nonambigua Lange-Bertalot, Cavacini, Tagliaventi \& Alfinito (Figs 10: 1-8; 11: 1-10)}

Valve morphology, LM: Valves are rhombic-lanceolate to elliptic-lanceolate with abruptly protracted and sub-capitate apices. Valve margin is 
gradually narrowing towards the apices in the larger and medium-sized specimens, while in smaller specimens (Figs 11: 6-10) "shoulders" might be present. Valve length varies from 49-66 $\mu \mathrm{m}$, valve width $12.5-18.0 \mu \mathrm{m}$. Axial area is very narrow, linear. Central area is absent to slightly wider than axial area. Raphe is straight, filiform. Proximal raphe endings are expanded into central pores and slightly deflected, while distal endings are hooked and reaching the valve mantle at the apex. Transapical striae radiate in the mid-valve, becoming slightly convergent towards the apices, 14-18 in $10 \mu \mathrm{m}$. Areolae are hardly visible with LM, 30-35 in $10 \mu \mathrm{m}$.

Similar species: Craticula ambigua, $C$. lange-bertalotii and $C$. fumantii Lange-Bertalot, Cavacini, Tagliaventi \& Alfinito (Lange-Bertalot et al. [11, Figs 8: 1-8; 9: 1-10]). Craticula nonambigua and C. ambigua can be hardly differentiated by the valve size. The main difference is that the valve margins in C. ambigua have "shoulders" near the apices. Craticula lange-bertalotii has wider valves (width $=21-25 \mu \mathrm{m}$ ) with slightly undulated margins. Craticula fumantii has narrower, lanceolate valves (not rhombic-lanceolate or ellipticlanceolate as in C. nonambigua).

Distribution in Macedonia: During this study, $C$. nonambigua was observed only in a small, temporary pond on halomorphic soils, Ovče Pole, near the town of town of Sveti Nikole. However, some other records of C. ambigua in Macedonia might belong to this species or to $C$. fumantii.

Ecology: Not precisely known. During this study, C. nonambigua was observed in an alkaline dystrophic pond and channel on halomorphic soils with high electrolyte content (high conductivity).

\section{Craticula fumantii Lange-Bertalot, Cavacini, Tagliaventi \& Alfinito}

(Figs 7: 4-8; 12: 1-11; 14: 1-3)

Valve morphology, LM (Figs 7: 4-8; 12: 111): Valves are strictly lanceolate, with abruptly protracted and sub-capitate apices. Valve length varies from 49-66 $\mu \mathrm{m}$, valve width 11.5-13.5 $\mu \mathrm{m}$. Axial area is very narrow, linear. Central area is absent to slightly wider than axial area. Raphe is straight, filiform. Proximal raphe endings are expanded into central pores and slightly deflected, while distal endings are hooked and reaching the valve mantle at the apex. Transapical striae radiate in the mid-valve, becoming slightly convergent towards the apices, 16-20 in $10 \mu \mathrm{m}$. Areolae are hardly visible with LM, 30-35 in $10 \mu \mathrm{m}$.

Valve morphology, SEM (Figs 14: 1-3): The valve surface is flat, without developed longitudinal frets (Figs 14: 1,2). Raphe is located on a moderately wide, strongly thickened sternum, slightly expanded in the central area (Fig. 14: 2). External proximal raphe endings are short, expanded into central pores and slightly unilaterally deflected (Fig. 14: 2). Distally, raphe endings are long, hooked and continuing onto the mantle (Fig. 14: 3). Striae are strongly radiate, uniseriate, composed mainly of round areolae. Areolae near the raphe sternum, and especially around the central area have larger, slightly elongated to ovate foramina (Fig. 14: 2). Internally, central nodule is slightly raised. Raphe branches are straight located on inwardly strongly elevated sternum. Raphe proximally terminates with short, simple endings, while distally with well developed helictoglossa. Areolae are covered by hymenes, located inside each areola (figure not shown).

Similar species: Craticula ambigua, C. nonambigua and C. johnstoniae Bahls [34, Figs 9095]. Craticula ambigua and C. nonambigua appear very similar to $C$. fumantii. Although LangeBertalot et al. [11, p. 34] stated that there is a difference in the striae density between $C$. ambigua and $C$. fumantii, in this study that cannot be confirmed. Differentiation between these three species can be made in combination of valve shape and size. Craticula ambigua and $C$. nonambigua are wider (14.5-20.0 $\mu \mathrm{m}$ and $12.5-18.0 \mu \mathrm{m}$ respectively) with elliptic-lanceolate to rhombic-lanceolate valve outline. Craticula johnstoniae has similar valve outline as $C$. fumantii, but the valves are larger (length 68-113 $\mu \mathrm{m}$, width 15.6-19.5 $\mu \mathrm{m}$ ).

Distribution in Macedonia: Craticula fumantii has been observed on two localities in Macedonia: Lake Karanikoličko on Šara Mountain and the River Buturica, Mariovo.

Ecology: Not precisely known. In Macedonia it was observed in an oligotrophic lake and river, slightly acidic to circumneutral, with low mineral content.

\section{Craticula germainii Lange-Bertalot, Cavacini,} Tagliaventi \& Alfinito (Figs 13: 1-17; 14: 4, 5)

Valve morphology, LM (Figs 13: 1-17): Valves are linear-lanceolate to elliptic-lanceolate, with sub-capitate to rostrate and broadly rounded apices. Valve length varies from $32-43 \mu \mathrm{m}$, valve width $9.0-11.5 \mu \mathrm{m}$. Axial area is very narrow, linear. Central area is well defined, lanceolate. Striae around central area more distantly spaced. Raphe is straight, filiform. Proximal raphe endings are expanded into central pores and slightly deflected, while distal endings are hooked and reaching the valve mantle at the apex. Transapical striae are ra- 
diate to strongly radiate, becoming convergent near the apices, $14-20$ in $10 \mu \mathrm{m}$. Areolae are not visible with LM.

Valve morphology, SEM (Figs 14: 4, 5): The species is rare in the sample and SEM observations of the valve exterior were not possible and only valve interior was observed. Internally, central nodule is distinct, elliptical and slightly raised (Fig. 14: 5). Raphe branches are straight located on inwardly strongly elevated sternum (Fig. 14: 4). Raphe proximally terminates with short, slightly deflected endings, while distally with well developed helictoglossa (Fig. 14: 4). Striae are strongly radiate, uniseriate, composed mainly of round areolae. Areolae probably are covered by hymenes, but due to the cleaning process, hymens are corroded. Areolae have slightly transapically elongated internal foramina (Fig. 14: 4).

Comment: The population of $C$. germainii from Macedonia is characterized by smaller valves compared to the type population (length $42-58 \mu \mathrm{m}$, width $11.5-13.5 \mu \mathrm{m})$. Additionally, difference in the striae orientation between this and the type population can be noticed. The striae in the type population are more or less equally spaced, are parallel to slightly radiate throughout the valve, while the observed valves in this study have more distantly spaced striae in the mid-valve and distinctly radiate striae. No SEM images are available for $C$. germainii, so ultrastructural features cannot be compared. In this moment we consider this population as conspecific with $C$. germainii, but further studies might suggest their separation into two taxa.

Similar species: Craticula germainii has unique set of characters (valve shape, striae orientation) that make its identification simple and cannot be confused with other species. Craticula simplex (Krasske) Levkov comb. nov. and C. accomodiformis Lange-Bertalot have comparable valve size, but they significantly differ in valve shape.

Distribution in Macedonia: Craticula germainii was observed only in a small, temporary pond on halomorphic soils, Ovče Pole, near the town of Sveti Nikole.

Ecology: Craticula germainii prefers alkaline dystrophic waters with high electrolyte content (high conductivity) such as temporary ponds and alkaline ferns.

\section{Craticula minusculoides (Hustedt)}

Lange-Bertalot (Figs 13: 18, 19; 20: 1)

Valve morphology, LM (Figs 13: 18, 19): Valves are elliptic to elliptic-lanceolate with narrowly rounded and not protracted apices. Valve length varies from 14-15 $\mu \mathrm{m}$, valve width 4.5-5.0 $\mu \mathrm{m}$. Axial area is very narrow, linear. Central area is absent or weakly expressed. Raphe is straight, filiform. Proximal raphe endings are slightly expanded into central pores, while distal endings are curved and terminating on the valve face near the valve apex. Transapical striae parallel throughout the valve, $25-28$ in $10 \mu \mathrm{m}$. Areolae are not visible with LM, c. 50 in $10 \mu \mathrm{m}$.

Valve morphology, SEM (Fig. 20: 1): The valve surface is flat, without developed longitudinal frets. Well developed sternum is absent. Raphe branches are straight and proximally terminate with expanded central pores. Distally, raphe endings are long, curved and not continuing on the valve mantle. Striae are parallel throughout the whole valve, uniseriate, composed of slightly elongated areolae.

Similar species: Craticula minusculoides can be confused with $C$. molestiformis (Hustedt) Mayama (Figs 18: 31-58) and C. subminuscula (Manguin) C.E.Wetzel \& Ector (Figs 21: 31-69). These three species can be clearly separated with SEM. In C. minusculoides the areolae are not occluded with hymens externally as in the other two species (compare with Figs 20: 2-5 and Figs 23: 14). The distal raphe endings in $C$. molestiformis are long, strongly hooked and continuing onto the valve mantle (Figs 20: 2-5). In C. subminuscula the distal raphe endings are short, strongly deflected and not passing on the valve mantle (Figs 23: 1-4), while in C. minusculoides they are curved and terminating on the valve face. The areolae in $C$. subminuscula and $C$. molestiformis have round foramina, while in $C$. minusculoides the areolae have transapically elliptical foramina.

Distribution in Macedonia: Craticula minusculoides was observed only in a small, temporary pond on halomorphic soils, Ovče Pole, near the town of Sveti Nikole. It is extremely rare in the sample.

Ecology: Not precisely known. According to Lange-Bertalot [10, p. 115] it occurs in electrolyte rich, eutrophic, $\alpha-\beta$ mesosaprobic waters. The locality where it was observed is characterized by slightly alkaline water $(\mathrm{pH}=8.3)$ with high conductivity $\left(1300 \mu \mathrm{S} \bullet \mathrm{cm}^{-1}\right)$.

\section{Craticula accomodiformis Lange-Bertalot}

(Figs 15: 1-20)

Valve morphology, LM: Valves are ellipticlanceolate to elliptic with shortly rostrate apices. Valve length varies from $32-50 \mu \mathrm{m}$, valve width $10.5-13.0 \mu \mathrm{m}$. Axial area is very narrow, linear. Central area is small, lanceolate. Raphe is straight, filiform. Proximal raphe endings are expanded into 
central pores and slightly deflected, while distal endings are hooked and reaching the valve mantle at the apex. Transapical striae are parallel in the mid-valve, becoming convergent near the apices, 19-21 in $10 \mu \mathrm{m}$. Areolae are hardly visible with LM, c. 35 in $10 \mu \mathrm{m}$.

Similar species: Craticula accomodiformis can be confused with $C$. accomoda (Hustedt) D.G. Mann and C. halophila (Grunow) D.G. Mann. Craticula accomoda can be easily differentiated by its smaller valves (length 18-22 $\mu \mathrm{m}$, width 6.0-7.5 $\mu \mathrm{m})$, while $C$. halophila has different valve shape (rhombic to rhombic-lanceolate)

Comment: The population of C. accomodiformis observed in this study is characterized by larger valves than type population (length 24-37 $\mu \mathrm{m}$, width $8-11.5 \mu \mathrm{m})$.

Distribution in Macedonia: Craticula accomodiformis was observed only on two localities, Negorska Banja and Banjsko.

Ecology: Both localities where C. accomodiformis was observed are thermo-mineral springs with high electrolyte content. The type population originates from Syria (Lange-Bertalot [9, Figs 69: 6-8, 10]), and was infrequently observed in Europe, mainly in the regions with a Mediterranean climate (Lange-Bertalot [10]).

\section{Craticula halophila (Grunow) D.G.Mann (Figs 16: 1-18)}

Basionym: Navicula cuspidata var. halophila Grunow in Van Heurck [42, p. 100, Suppl. pl. B, Fig. 30]

Nomenclatural synonym: Navicula halophila (Grunow) Cleve [36, p. 109]

Valve morphology, LM: Valves are rhombic to rhombic-lanceolate with acute to slightly protracted apices. Valve length varies from $27-54 \mu \mathrm{m}$, valve width $9.0-12.0 \mu \mathrm{m}$. Axial area is very narrow, linear. Central area is absent with same width as axial areal. Raphe is straight, filiform. Proximal raphe endings are expanded into central pores and slightly deflected, while distal endings are hooked and reaching the valve mantle at the apex. Transapical striae are parallel to slightly radiate in the mid-valve becoming strongly convergent towards the apices, 17-19 in $10 \mu \mathrm{m}$. Areolae are hardly visible with LM, c. 35 in $10 \mu \mathrm{m}$.

Similar species: Craticula halophila can be hardly confused with other species, since it has characteristic valve shape that makes its identification simple. Craticula accomodiformis LangeBertalot has similar size, but it has ellipticlanceolate valves with shortly rostrate apices.
Distribution in Macedonia: So far, C. halophila was observed only in temporary ponds on Slan Dol. It was reported from Lake Dojran, but this data was not confirmed during this study.

Ecology: Halophilic species, occurring in salt springs and ponds with high content of salts.

Craticula simplex (Krasske) Levkov comb. nov. (Figs 17: 1-38; 18: 1-20; 19: 1-6)

Basionym: Navicula simplex Krasske [43], Abhandlungen und Bericht LVI des Vereins für Naturkunde zu Cassel, 84-89 Vereinsjahr 19191925, p. 51, Fig. 2: 33.

Valve morphology, LM (Figs 17: 1-38; 18: 1-20): Valves are lanceolate, linear-lanceolate to rhombic-lanceolate with shortly protracted, rostrate to subcapitate apices. Valve length varies from 19$37 \mu \mathrm{m}$, valve width $5.5-8.5 \mu \mathrm{m}$. Axial area is narrow, linear. Central area is absent or weakly developed, slightly wider than the axial area. Raphe is straight, filiform. Proximal raphe endings are expanded into central pores and are slightly deflected, while distal endings are hooked and reaching the valve mantle at the apex. Transapical striae are parallel to slightly radiate in the mid-valve becoming convergent towards the apices, 17-19 in $10 \mu \mathrm{m}$. Areolae are not visible with LM.

Valve morphology, SEM (Figs 19: 1-6): The valve surface is flat without longitudinal frets (Figs 19: 1, 2, 4). The axial area is moderately wide. Raphe branches are straight. External proximal raphe endings are short, expanded into small central pores and unilaterally deflected (Fig. 19: 4). Distally, raphe endings are long, strongly hooked and continuing onto the mantle (Fig. 19: 5). Striae are uniseriate composed of large, apically elongated like areolae, except near the central area where areolae have elliptical foramina (Fig. 19: 4). Internally, central nodule is slightly raised (Fig. 19: 5). Raphe branches are straight located on inwardly slightly elevated raphe sternum. Raphe proximally terminates with short, slightly deflected endings, while distally with weakly developed helictoglossa. Areolae are covered by hymenes, located inside each areola (Fig. 19: 4).

Comment: The observed species has similar characteristics as Navicula simplex Krasske [43, Fig. 2: 33]. In the past, this taxon was recognized as a separate and distinct species by Hustedt [44, p. 296, fig. 500], and there are several records in the older literature. More recently, Hustedt's concept of $N$. simplex was presented by Krammer \& LangeBertalot [19, Fig. 44: 6]. However, later LangeBertalot [10, p. 110] considered this species as a 
part of the life cycle of $N$. buderi Hustedt [45, p. 279, figs 11-15] $\equiv C$. buderi (Hustedt) LangeBertalot (in Rumrich et al. [13, p. 101]). The type material of $N$. buderi was observed with LM and SEM by Ector \& Wetzel (pers. comm.) and both species considerably differ with respect to the valve shape and size.

During this study three different morphotypes of $C$. simplex were observed. The first morphotype (Figs 17: 1-18; 18: 11-21), is characterized by larger (26-37 $\mu \mathrm{m}$ long, $7.0-8.5 \mu \mathrm{m}$ wide) and lanceolate valves with subcapitate apices. This morphotype is the most commonly observed during this study. The second morphotype (Figs 17: 1938) has smaller (23-27 $\mu \mathrm{m}$ long, 5.5-6.0 $\mu \mathrm{m})$ lanceolate valves with rostrate apices. This population was observed as epiphyte in temporary ponds on Slan Dol. The third morphotype (Figs 18: 1-10) is characterized by smaller (19-26 $\mu \mathrm{m}$ long, $6.0-7.0$ $\mu \mathrm{m}$ wide) linear-lanceolate valves with shortly rostrate apices. This morphotype was observed in sediments from saline temporary ponds. However, all habitats are characterized with same ecology: higher temperature (around $30{ }^{\circ} \mathrm{C}$ ) and high mineral content (conductivity $1200-2000 \mu \mathrm{S} \cdot \mathrm{cm}^{-1}$ ). Although clear difference in the valve morphology between these three populations can be noticed, we still consider them as conspecific, being a part of the morphological variability of a single species.

Similar species: Craticula simplex is similar to C. guaykuruorum C.E.Wetzel, E.Morales \& Ector (in Morales et al. [12, Figs 15-23, 31-37]), C. elkab (O. Müller ex O. Müller) Lange-Bertalot, Kusber \& Cocquyt (Kusber \& Cocquyt [46]), $C$. riparia (Hustedt) Lange-Bertalot and $C$. antarctica Van de Vijver \& Sabbe (in Van de Vijver et al. [14, figs 19-36]). Craticula simplex can be differentiated from $C$. guaykuruorum by the shape of valve apices (narrow and weakly protracted), stria density (21-23 in $10 \mu \mathrm{m})$ and orientation (parallel in $C$. guaykuruorum) as well as by the absence of longitudinal frets. Craticula elkab has comparable valve size and shape with morphotype 3 (Figs 18: 1-10), but it differs with the shape of the valve apices (narrowly rounded to weakly protracted especially in larger specimens) and striae density (22-26 in 10 $\mu \mathrm{m})$. Craticula riparia var. riparia is characterized by larger valves $(35-50 \mu \mathrm{m}$ long, $8.0-10.5 \mu \mathrm{m}$ wide) with $15-18$ striae in $10 \mu \mathrm{m}$ which are parallel through. Craticula riparia var. mollenhaueri Lange-Bertalot [9, figs 70: 10-13) has comparable valve size as $C$. simplex, but can be differentiated by the presence of strongly silicified raphe sternum and striae orientation (parallel in $C$. riparia var. mollenhaueri). Probably the most similar species to
C. simplex is $C$. antarctica. The latter species is characterized by lanceolate valves with (sub) capitate apices, 23.5-36.0 $\mu \mathrm{m}$ long and 6.2-8.0 $\mu \mathrm{m}$ wide with $17-22$ striae in $10 \mu \mathrm{m}$ which are radiate in the middle, becoming convergent towards apices. Slight difference between these two species can be noticed in the valve shape (rhombic lanceolate vs. elliptic lanceolate in $C$. antarctica) and valve apices (rostrate vs. capitate $C$. antarctica). Difference can be noticed also in ecology: Craticula antarctica was observed in a cold lake on Antarctica, while $C$. simplex was observed in thermo-mineral springs and warm temporary ponds on halomorphic soils.

Distribution in Macedonia: Craticula simplex was observed on several localities in Macedonia: halomorphic soils in Sveti Nikole and Gladno Pole, the thermo-mineral springs near the villages Gabrovo, Stamer and Katlanovo, temporary ponds in Slan Dol and mining Lake Usje.

Ecology: Halophilic and alkaliphilic species, present in mineral springs, temporary ponds on halomorphic soils, mining lakes.

\section{Craticula accomoda (Hustedt) D.G.Mann}

(Figs 18: 21-30; 21: 1-30; 22: 1-6)

Basionym: Navicula accommoda Hustedt [47, p. 446, Figs 39: 17, 18]

Valve morphology, LM (Figs 18: 21-30; 21: 1-30): Valves are elliptic-lanceolate to elliptic with shortly rostrate apices. Valve length varies from $18-22 \mu \mathrm{m}$, valve width $6.0-7.5 \mu \mathrm{m}$. Axial area is very narrow, linear. Central area is absent or weakly expressed with almost the same width as axial area. Raphe is straight, filiform. Proximal raphe endings are expanded into central pores and slightly deflected, while distal endings are hooked and reaching the valve mantle at the apex. Transapical striae are parallel to slightly radiate in the mid-valve becoming convergent towards the apices, $22-28$ in $10 \mu \mathrm{m}$. Areolae are not visible with LM.

Valve morphology, SEM (Figs 22: 1-6): The valve surface is flat, without developed longitudinal frets (Figs 22: 1-4). Axial area is very narrow. Raphe is linear, located on the valve surface (Figs 22: 1-4). External proximal raphe endings are short, straight and slightly expanded into central small pores (Fig. 22: 4). Distally, raphe endings are long, strongly hooked and terminating on the valve face (Figs 22: 1-3). Striae are uniseriate composed of narrow, apically elongated slit-like areolae. Areolae around central area have transapically elongated foramina (Fig. 22: 4). Internally, central nodule is distinctly raised (Figs 22: 5, 6). Raphe branches are straight located on inwardly strongly elevated 
sternum (Fig. 22: 6). Raphe proximally terminates with short slightly deflected endings, while distally with slightly developed helictoglossa. Areolae are covered by hymenes, located inside each areola (Figs 22: 5, 6).

Similar species: Craticula accomoda can be hardly confused with other species. Craticula accomodiformis is larger (32-50 $\mu \mathrm{m}$ long, 10.5-13.0 $\mu \mathrm{m}$ wide), while $C$. molestiformis (Hustedt) Mayama is smaller (9.5-22 $\mu \mathrm{m}$ long and 3-5 $\mu \mathrm{m}$ wide) with weakly protracted apices. Craticula simplex MT3 has comparable valve size, but it can be easily differentiated by the stria density and orientation.

Distribution in Macedonia: During this study C. accomoda was observed in the rivers Vardar, Bregalnica, Strumica, Zrnovka, Kočanska, Svetinikolska, Vodenišnica, reservoir Kalimanci, halomorphic soils near Sveti Nikole and Gladno Pole, temporary ponds in Slan Dol and mining Lake Usje.

Ecology: Eutraphentic species, it was observed in the most polluted sites in rivers. In the River Vodenišnica (a heavy polluted river with communal and industrial waste waters) is one of the dominant species, together with $C$. subminuscula (Manguin) Wetzel \& Ector.

\section{Craticula molestiformis (Hustedt) Mayama} (Figs 18: 31-58; 20: 2-6)

Basionym: Navicula molestiformis Hustedt [48, p. 86, fig. 5: 9]

Valve morphology, LM (Figs 18: 31-58): Valves are elliptic to elliptic-lanceolate with narrowly rounded apices. Valve length varies from 9$16 \mu \mathrm{m}$, valve width $3.5-5.0 \mu \mathrm{m}$. Axial area is very narrow, linear. Central area is absent or weakly expressed. Raphe is straight, filiform. Proximal raphe endings are expanded into central pores, while distal endings are long, strongly hooked and continuing on the valve mantle. Transapical striae are parallel in the middle becoming slightly radiate towards the apices, 26-32 in $10 \mu \mathrm{m}$. Areolae are not visible with LM, c. 50 in $10 \mu \mathrm{m}$.

Valve morphology, SEM (Figs 20: 2-6): The valve surface is flat, without developed longitudinal frets (Figs 20: 2-5). Axial area is very narrow. Raphe is linear located on the valve surface (Figs 20: 2-5). External proximal raphe endings are short, straight and slightly expanded into small central pores (Figs 20: 2-5). Distally, raphe endings are long, strongly hooked and continuing onto valve mantle (Figs 20: 2, 4, 5). Striae are uniseriate composed of small elliptical areolae with same size. Externally, areolae are covered with hymens. Inter- nally, central nodule is slightly inwardly elevated (Fig. 20: 6). Raphe branches are straight located on inwardly weakly elevated sternum (Fig. 20: 6). Raphe proximally terminates with short and distinctly deflected endings, while distally with slightly developed helictoglossa. Areolae covered by hymenes, located inside each areola towards the outer valve surface (Fig. 20: 6).

Similar species: Craticula molestiformis can be confused with $C$. subminuscula. Both species have similar valve size and valve shape, but can be differentiated by the stria density $(26-32 / 10 \mu \mathrm{m} v \mathrm{~s}$ $22-26 / 10 \mu \mathrm{m})$. Additional differences can be observed in the raphe morphology. The distal raphe endings in C. molestiformis are long, strongly hooked and continuing onto the valve mantle (Figs 20: 2-5). In $C$. subminuscula the distal raphe endings are short, deflected and not passing on the valve mantle (Figs 23: 1-4). Craticula submolesta (Hustedt) Lange-Bertalot and C. molesta (Krasske) Lange-Bertalot \& Willmann have shortly rostrate apices.

Distribution in Macedonia: Craticula molestiformis was observed only in the reservoir Ratevsko. It is possible to have broader distribution in Macedonia, but very likely it is overlooked or misidentified with other small-celled species.

Ecology: According to Lange-Bertalot [10] C. molestiformis prefers electrolyte rich, often heavily polluted waters. However, during this study it was observed in the oligo- to mesotrophic reservoir and Lake Vevčansko on Mountain Jablanica.

\section{Craticula subminuscula (Manguin) C.E.Wetzel \& Ector (Figs 21: 31-69; 23: 1-6)}

Basionym: Navicula subminuscula Manguin [18, p. 139, Fig. 2: 39]

Nomenclatural synonym: Eolimna subminuscula (Manguin) Moser, Lange-Bertalot \& Metzeltin [49, p. 154]

Valve morphology, LM (Figs 21: 31-69): Valves are elliptic to narrowly to broadly rounded apices. Valve length varies from $8-14 \mu \mathrm{m}$, valve width 3.5-5.5 $\mu \mathrm{m}$. Axial area is very narrow, linear. Central area is absent or weakly expressed. Raphe is straight, filiform. Proximal raphe endings are expanded into central pores, while distal endings are short, deflected and not passing on the valve mantle. Transapical striae are radiate to strongly radiate throughout the valve, $22-24$ in $10 \mu \mathrm{m}$. Areolae are not visible with LM.

Valve morphology, SEM (Figs 23: 1-6): The valve surface is flat, without developed longitudinal frets (Figs 23: 1-4). Axial area is very nar- 
row. Raphe is linear located on the valve surface (Figs 23: 1, 4) or on slightly elevated sternum (Figs 23: 2, 3). External proximal raphe endings are short, weakly deflected and expanded into small central small pores (Figs 23: 1-4). Distally, raphe endings are short and unilaterally deflected and not continuing onto valve mantle (Figs 23: 1-4). Striae are uniseriate composed of small round areolae. Areolae near the valve face/mantle junction have larger external foramina (Figs 23: 2, 3). Externally, areolae are covered with slightly recessed hymens. Internally, central nodule is slightly inwardly elevated (Figs 23: 5, 6). Raphe branches are straight located on inwardly weakly elevated sternum (Figs 23: 5, 6). Raphe proximally terminates with short and slightly deflected endings, while distally with slightly developed helictoglossa. Areolae are covered by hymenes, located inside each areola towards the outer valve surface (Figs 23: 5, 6).

Comment: Craticula subminuscula was formerly transferred to the genus Eolimna LangeBertalot \& W.Schiller [in Schiller \& LangeBertalot 50] by Moser et al. [49]. More recently it was transferred to the genus Craticula by Wetzel $e t$ al. [51, p. 229], based on previously published morphological and molecular data. However, $C$. subminuscula and C. molestiformis have slightly different ultrastructural features than other Craticula species. The areola are externally occluded (Figs 20: 2-5 and Figs 23: 1-4) opposite to other Craticula species where the areolae are internally occluded. The shapes of the foramina in C. subminuscula and C. molestiformis are round opposite to slit-like areola in other Craticula species. Their allocation in the genus Craticula should be examined more in detail in the future.

Similar species: As mentioned above, $C$. subminuscula can be confused with $C$. molestiform$i s$, but both species can be easily differentiated by the raphe morphology, stria orientation and density.
Distribution in Macedonia: The rivers: Vodenišnica, Strumica, Bregalnica and Vardar. Probably it has wider distribution in polluted rivers, but very likely it is neglected or confused with other small-celled species. Hustedt [17] recorded this species from Lake Ohrid under $N$. demissa. However, during the recent observations of the flora of Lake Ohrid (Levkov et al. [52]) and this study, $N$. demissa (or C. subminuscula) was not recorded.

Ecology: Craticula subminuscula is one of the most tolerant species to organic pollution. During this study, this species was observed with high abundance in two of the most polluted rivers: Vodenišnica and Bregalnica.

\section{CONCLUSIONS}

The Republic of Macedonia is characterized by presence of various water habitats which host highly diverse diatom flora. Recently more attention was paid to the so called "extreme habitats". Those habitats include thermo-mineral springs, temporarily wet rocks, hypersaline lakes, wet halomorphic soils, ice layers and caves. Such habitats are unfavourable for most of the algae, but on the other hand, they are inhabited by specialized organisms which are adapted to numerous fluctuating and extremely adverse physico-chemical conditions. During this study the highest diversity of Craticula was observed exactly in such extreme habitats. A large number of species were observed on the halomorphic soils near Gladno Pole and Slan Dol. However, these regions are most intensively utilized for agriculture and farming which have a significant impact on their surface area and degradation. Moreover, the scenarios for climate change of the region of Gladno Pole suggest decrease of precipitation and increase of air temperature. Such alterations will have an influence on environment and the functioning of habitats. Therefore the distribution of the remarkable diatom species inhabiting these habitats is under threat. 

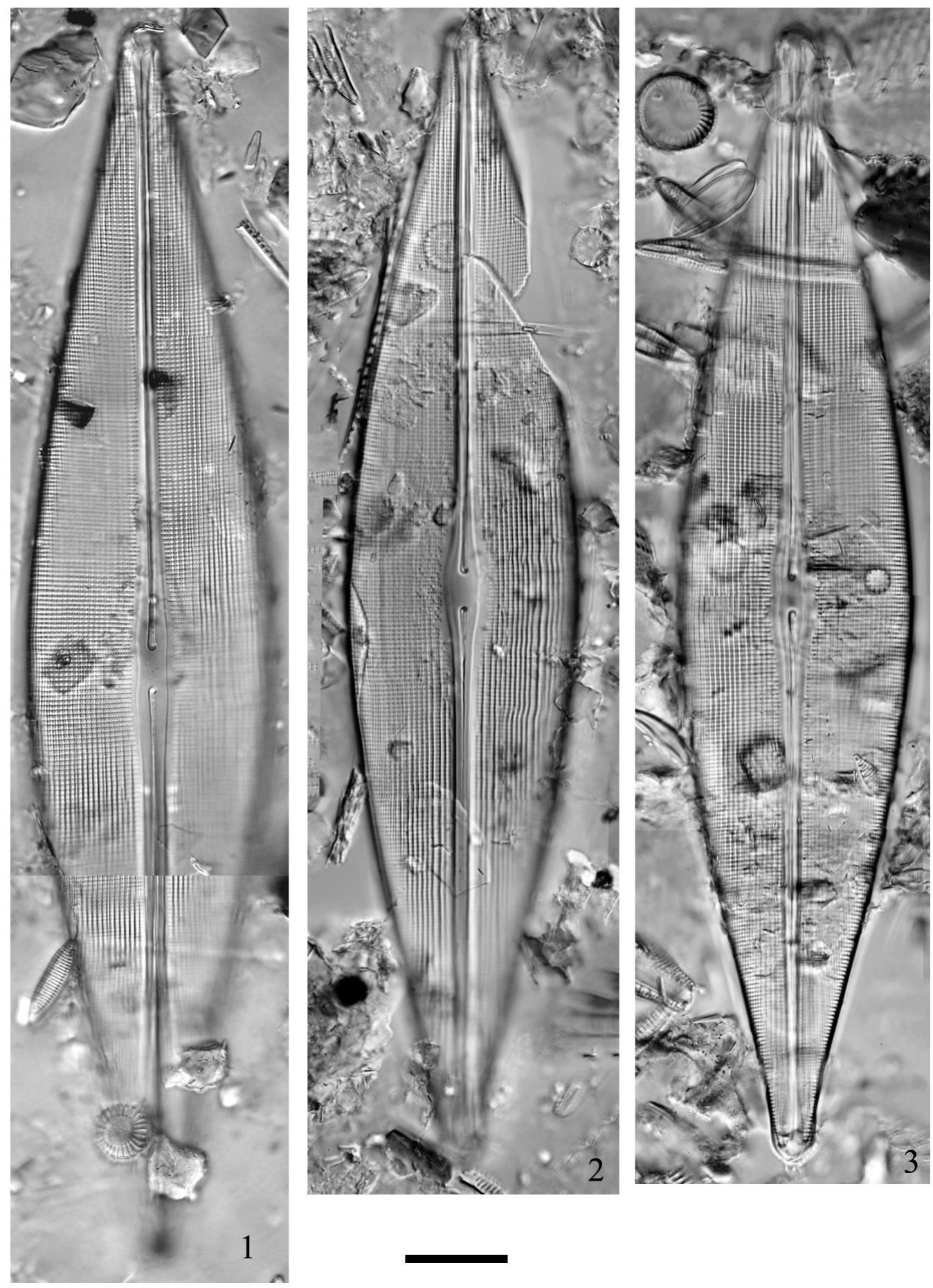

Figure 1: 1-3. Light micrographs (LM) of Craticula perrotettii Grunow. Lake Dojran, Alex Beach, plankton (Slide MKNDC 002212). Scale bar $=20 \mu \mathrm{m}$. 


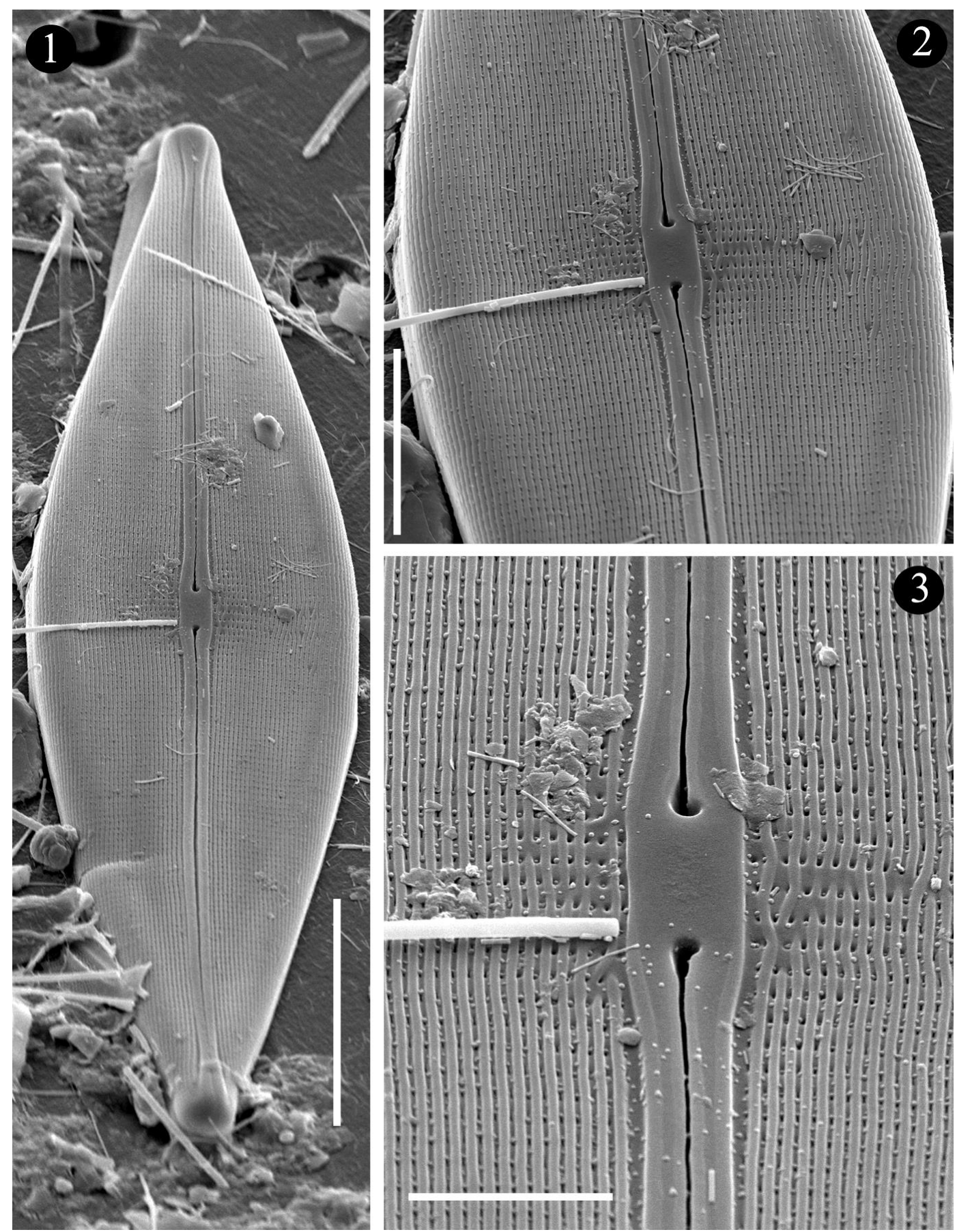

Figure 2: 1-3. Scanning electron micrographs of Craticula perrotettii. 1. External view of the whole valve. 2, 3. Detailed view of the mid-valve. Areolae are separated by strongly thickened frets (longitudinal ribs). Areolae in the mid-valve have round foramina, while distally have slit-like openings. Scale bar $=20 \mu \mathrm{m}(\mathbf{1}), 10 \mu \mathrm{m}(\mathbf{2}), 5 \mu \mathrm{m}(\mathbf{3})$. 

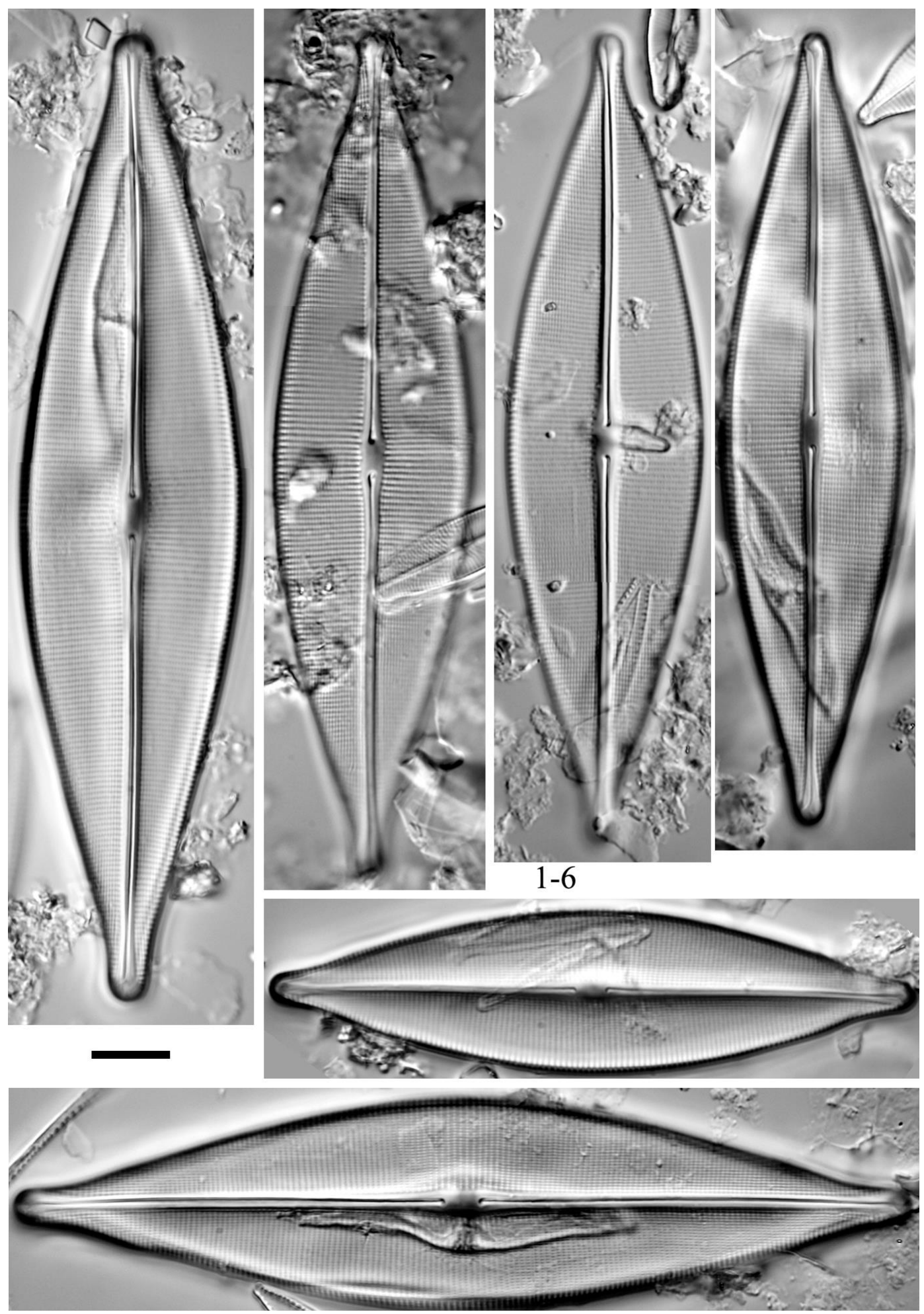

Figure 3: 1-6. LM micrographs of Craticula cuspidata (Kützing) D. G. Mann. The River Bregalnica, before the mouth of the River Kočanska, yellow filaments (Slide MKNDC 006806). Scale bar $=10 \mu \mathrm{m}$. 

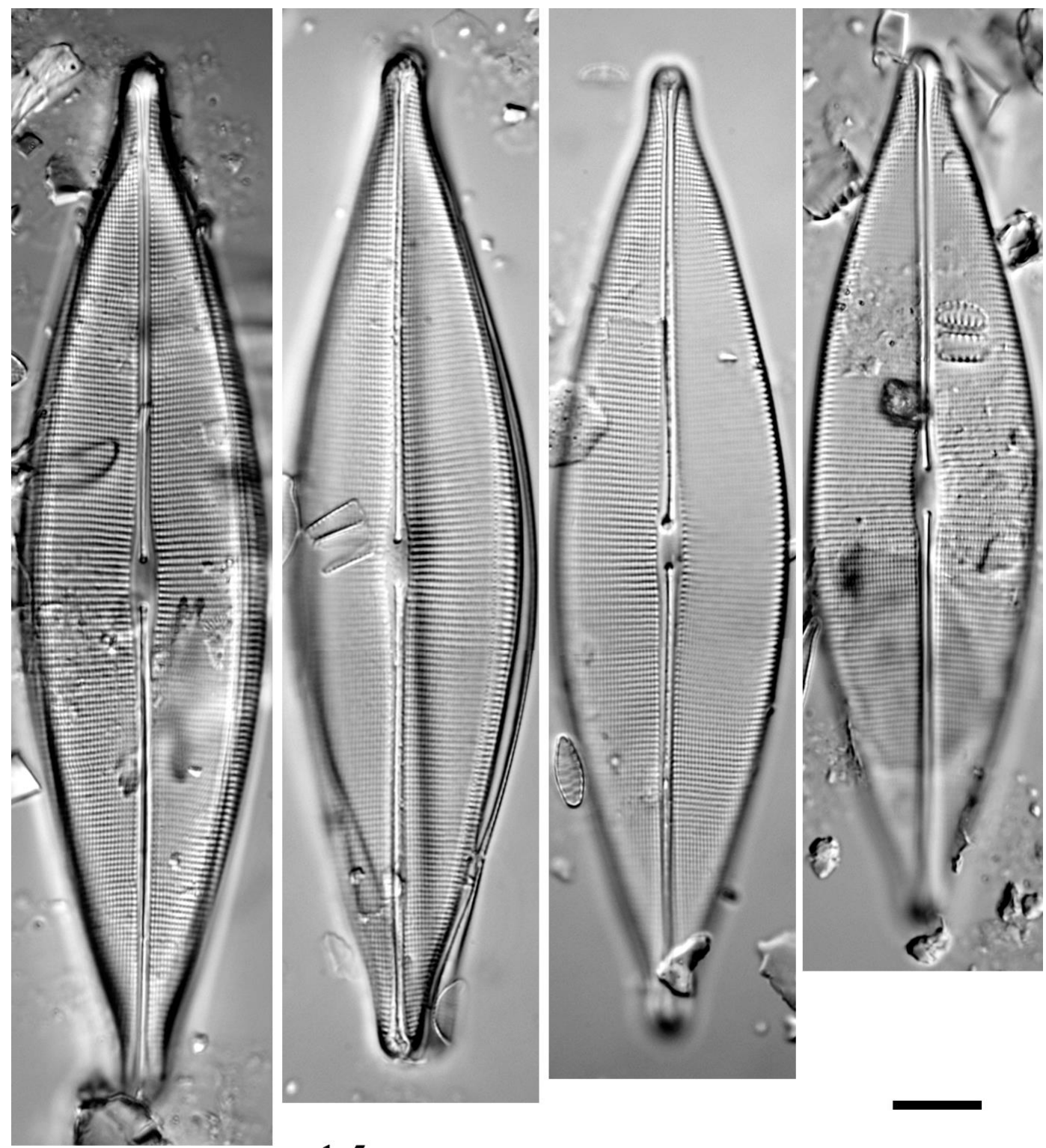

\section{$1-5$}

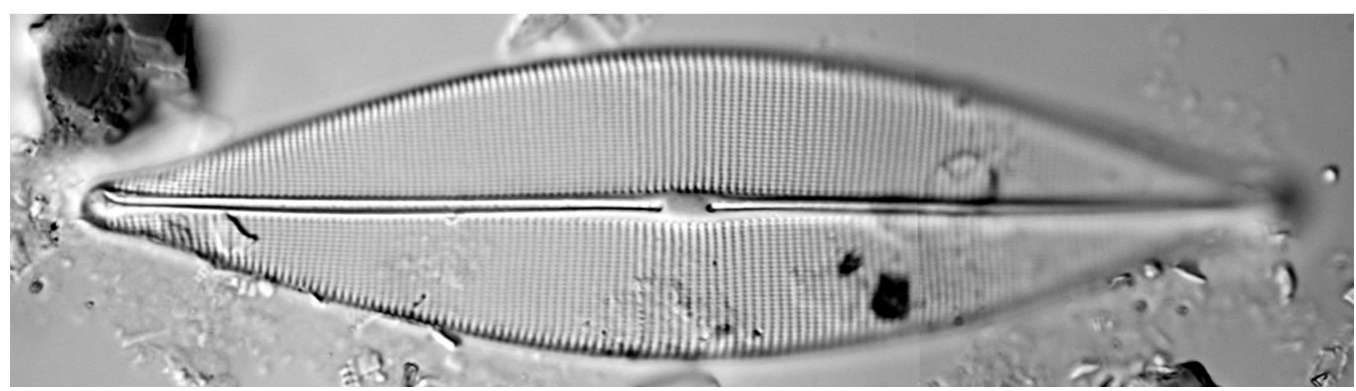

Figure 4: 1-5. LM micrographs of Craticula cuspidata (Kützing) D.G.Mann. Lake Ohrid, Bay of St. Naum, sediment $9 \mathrm{~m}$ depth (Slide MKNDC 001133). Scale bar $=10 \mu \mathrm{m}$. 

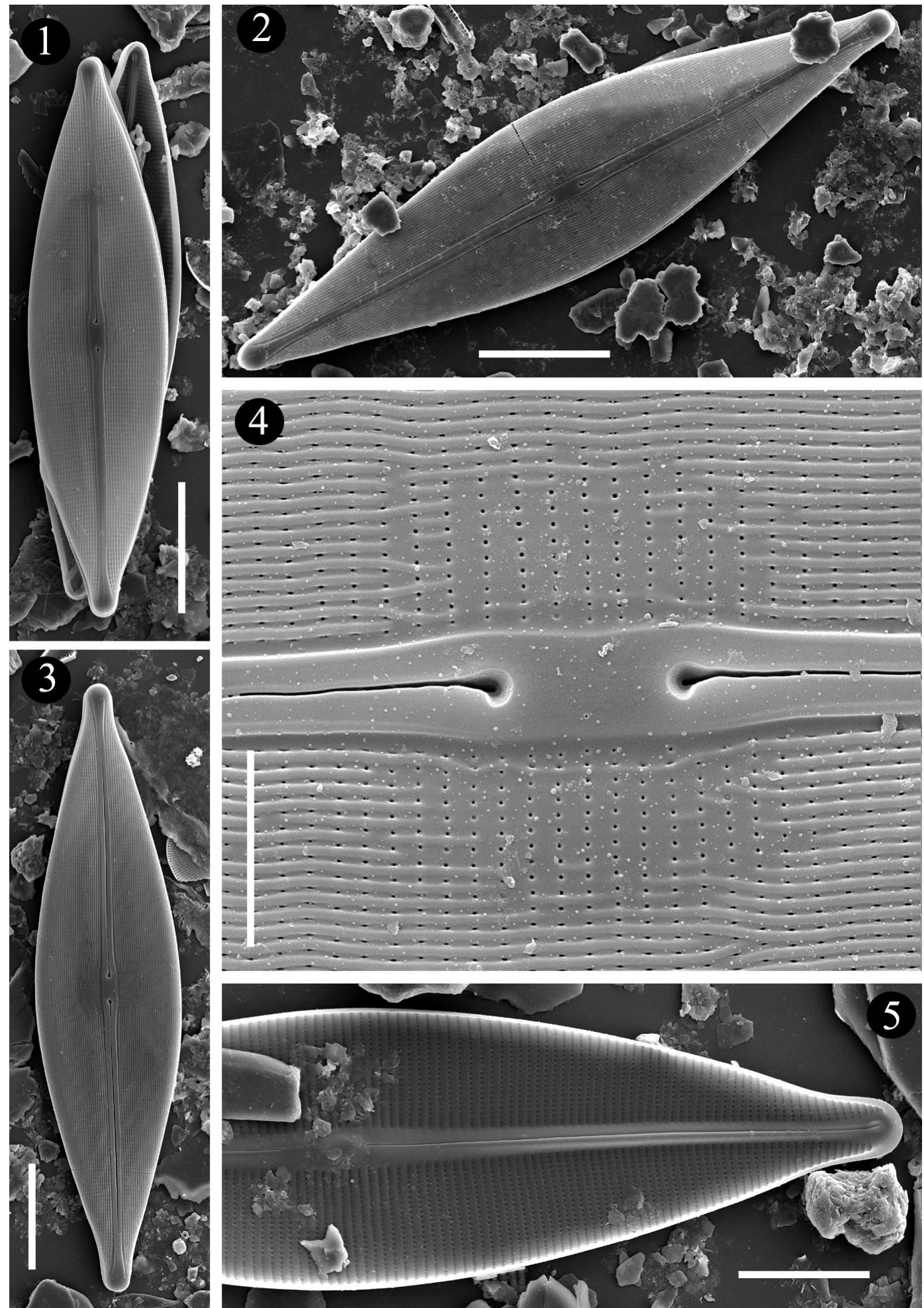

Figure 5: 1-5. Scanning electron micrographs of Craticula cuspidata. 1-3. External view of the whole valve. 4. Detailed view of the mid-valve. Areolae are separated by thickened frets (longitudinal ribs). Areolae in the mid-valve have round foramina, while distally have slit-like openings.

5. Internal view. Areolae are occluded by hymen. Scale bar $=20 \mu \mathrm{m}(\mathbf{1}-\mathbf{3}), 5 \mu \mathrm{m}(\mathbf{4}), 10 \mu \mathrm{m}(\mathbf{5})$. 

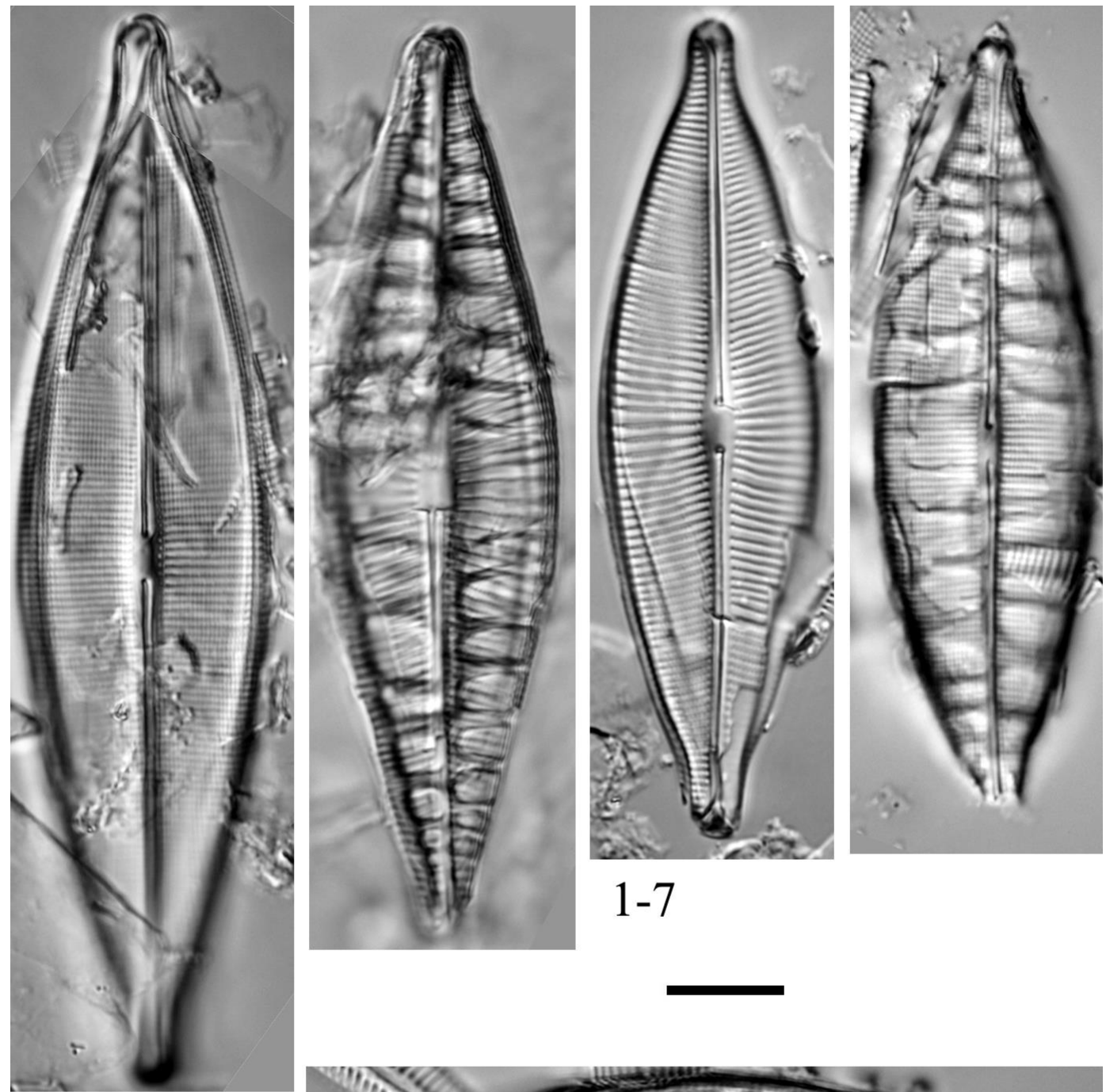

\section{1-7}
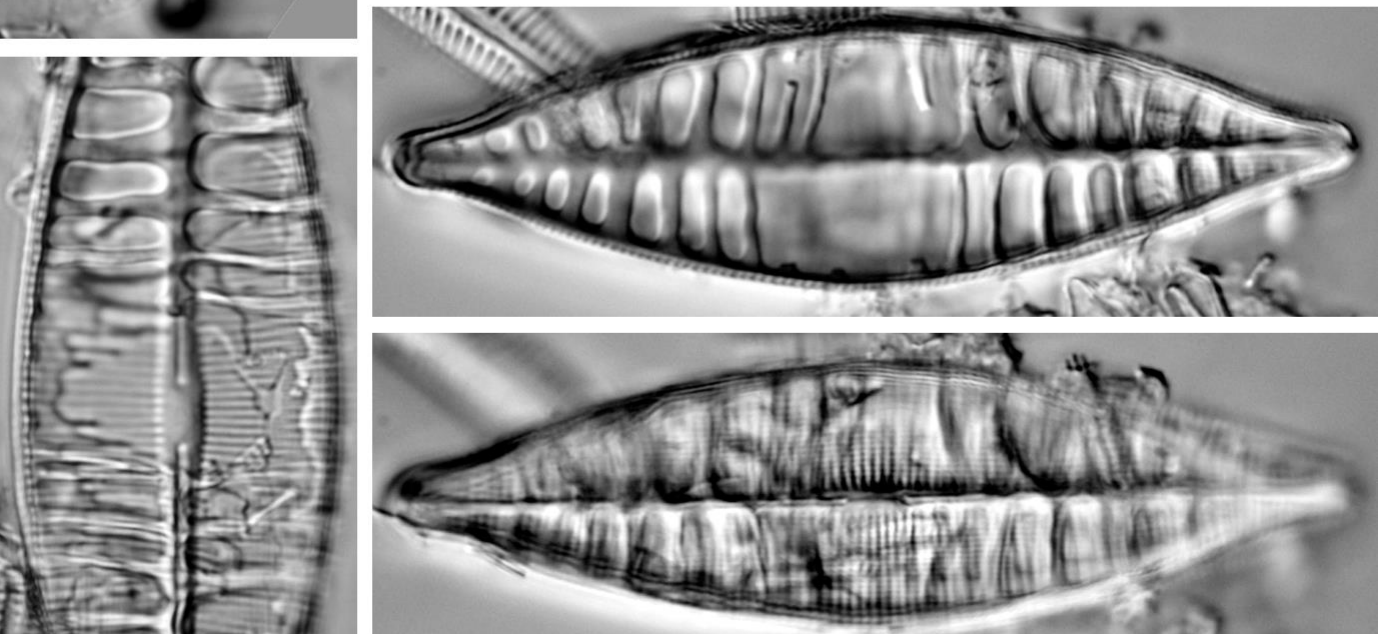

Figure 6: 1-7. LM micrographs of Craticula aff. acidoclinata Lange-Bertalot \& Metzeltin. Šara Mountain, Lake Karanikoličko, macrophytes (Slide MKNDC 003084). Scale bar $=10 \mu \mathrm{m}$. 

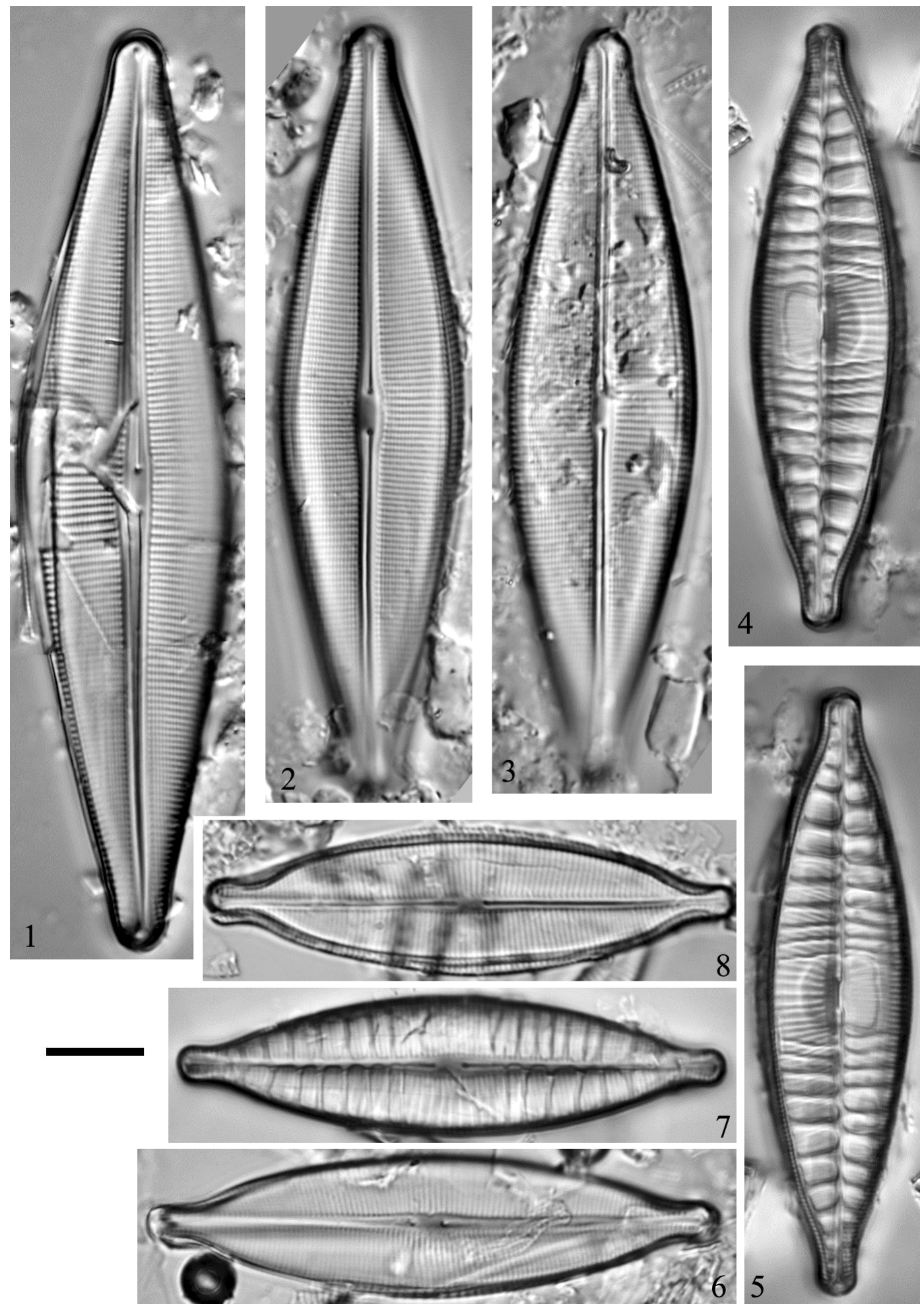

Figure 7: 1-3. LM micrographs of Craticula sardiniana Bahls. Sveti Nikole, the village of Adzimatovo, pond, sediment (Slide MKNDC 008835). 4-8. LM micrographs of Craticula fumantii Lange-Bertalot, Cavacini, Tagliaventi \& Alfinito. Lake Karanikoličko, Šara Mountain, macrophytes (Slide MKNDC 003084). Scale bar $=10 \mu \mathrm{m}$. 

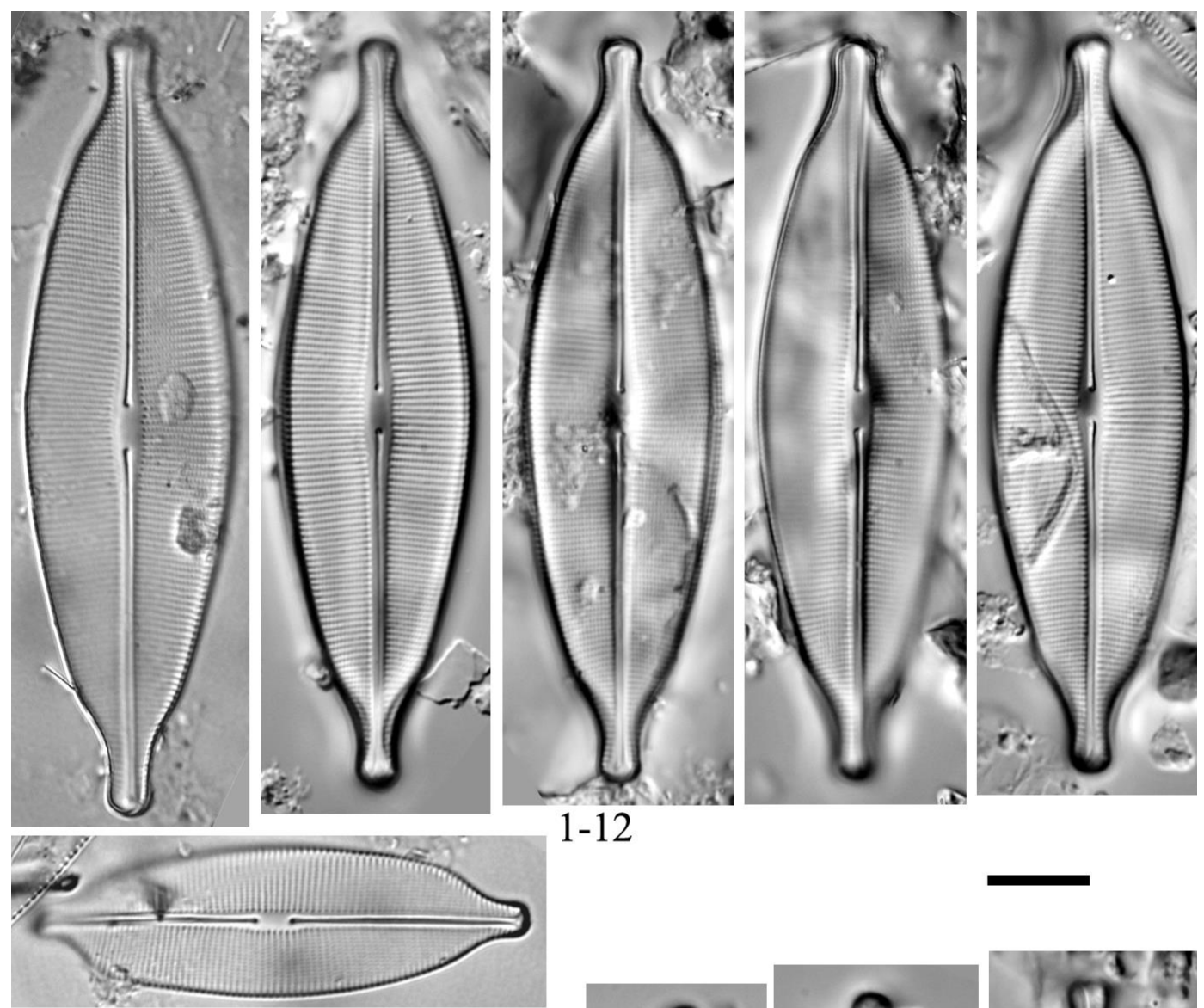

$1-12$
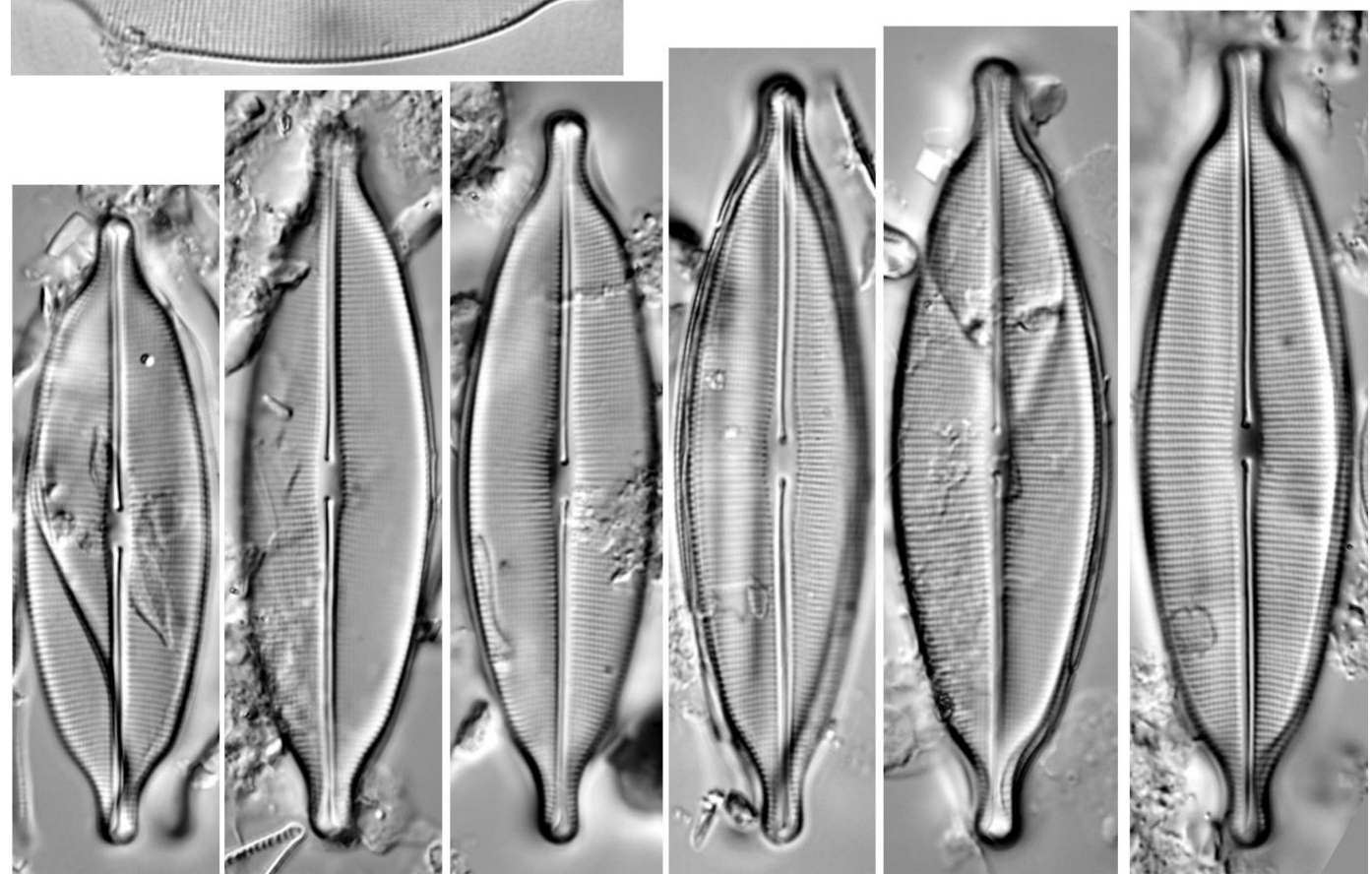

Figure 8: 1-12. LM micrographs of Craticula ambigua (Ehrenberg) D.G. Mann. The River Bregalnica, before the mouth of the River Kočanska, yellow filaments (Slide MKNDC 006806). Scale bar $=10 \mu \mathrm{m}$. 

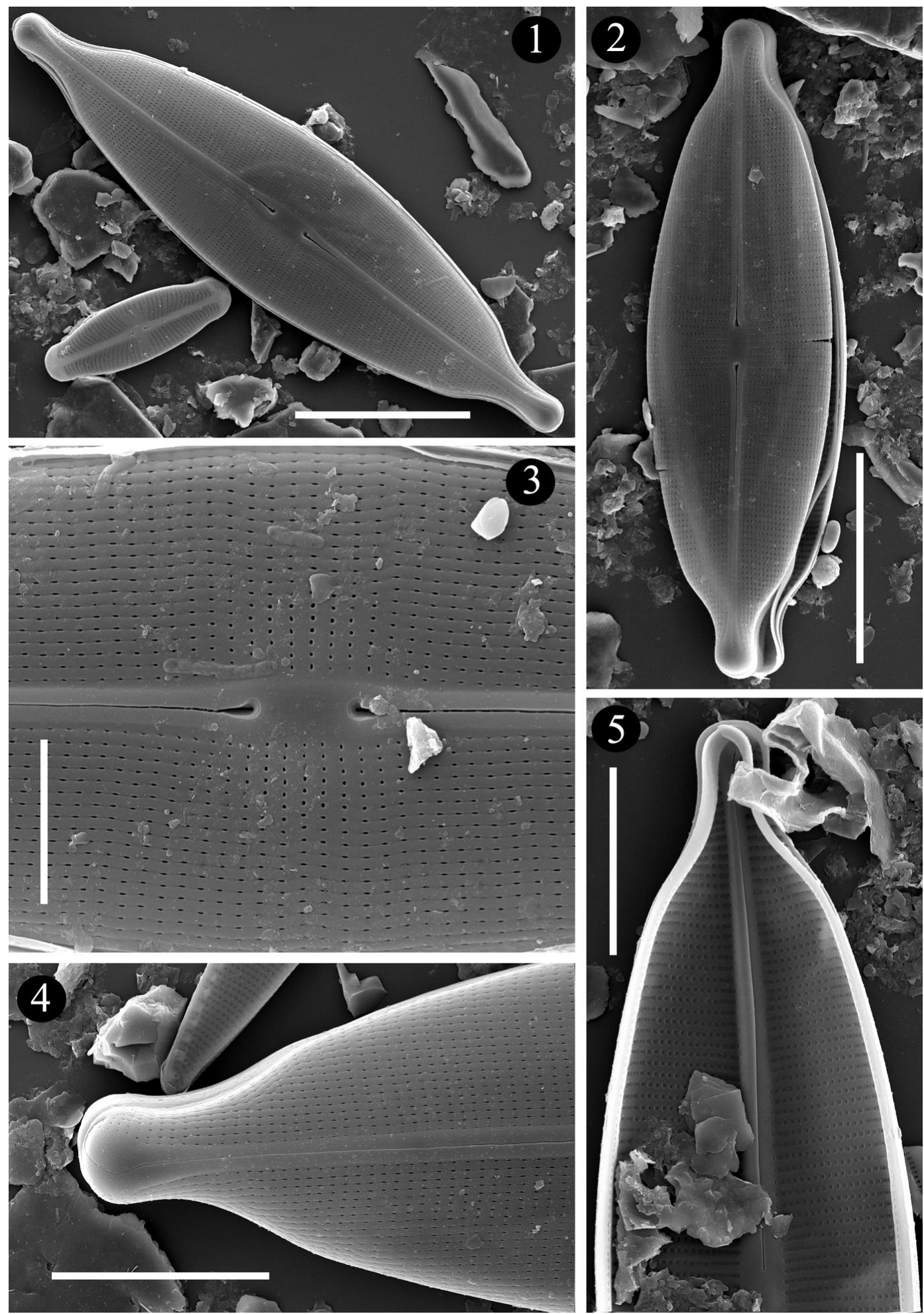

Figure 9: 1-5. Scanning electron micrographs of Craticula ambigua. 1, 2. External view of the whole valve.

3. Detailed view of the mid-valve. Areolae in the mid-valve have round foramina, while distally have slit-like openings. 4. Detailed view of the valve apex showing the "shoulder" and capitate apex.

5. Internal view. Areolae are occluded by hymen. Scale bar $=20 \mu \mathrm{m}(\mathbf{1 , 2}), 5 \mu \mathrm{m}(\mathbf{3}), 10 \mu \mathrm{m}(\mathbf{4 , 5})$. 

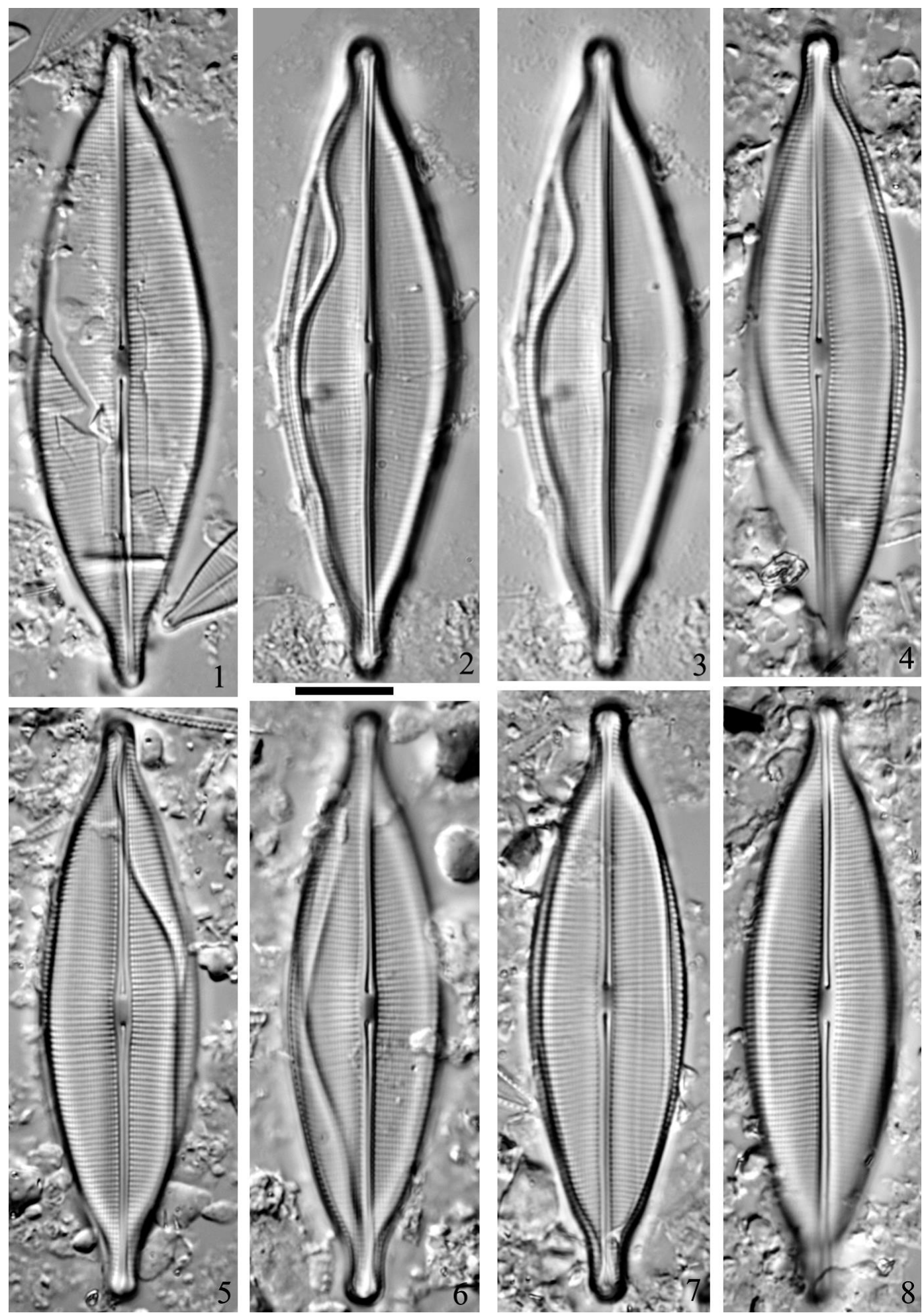

Figure 10: 1-8. LM micrographs of Craticula nonambigua Lange-Bertalot, Cavacini, Tagliaventi \& Alfinito. Sveti Nikole, near the village of Adzimatovo, pond, mud (Slides MKNDC 008835 and 008836). Scale bar $=10 \mu \mathrm{m}$. 

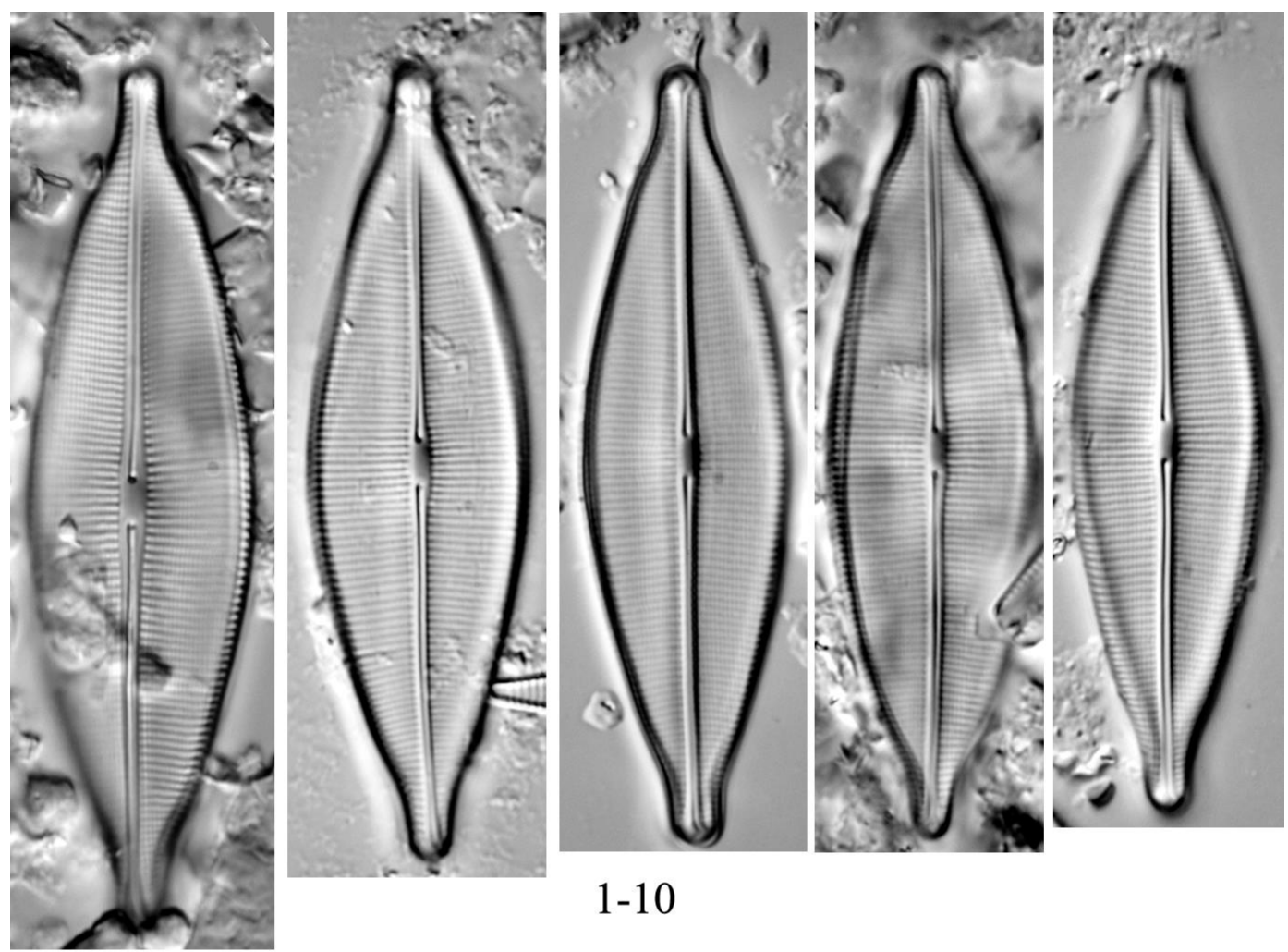

\section{$1-10$}
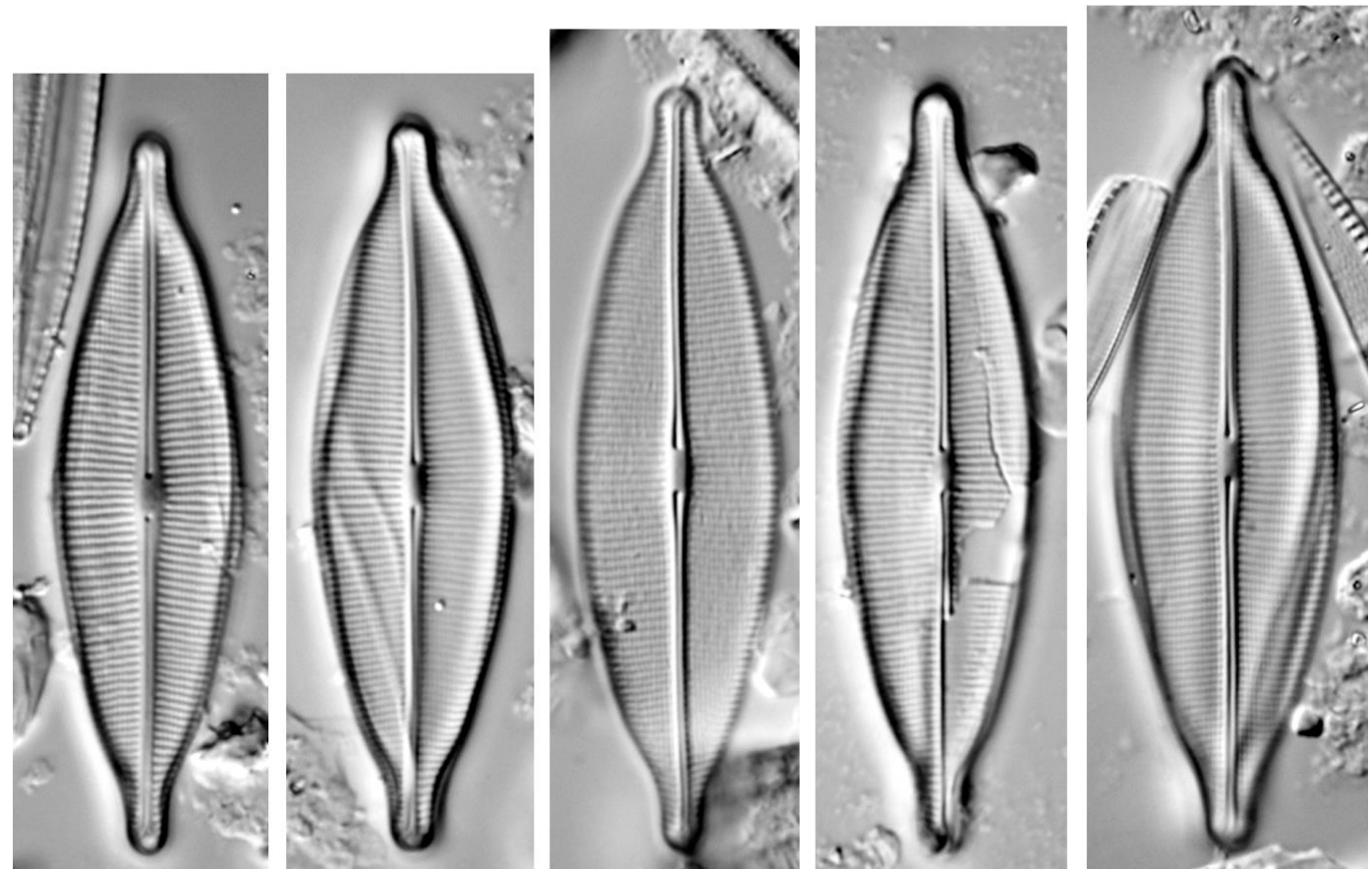

Figure 11: 1-10. LM micrographs of Craticula nonambigua Lange-Bertalot, Cavacini, Tagliaventi \& Alfinito. Sveti Nikole, near the village of Adzimatovo, pond, mud (Slides MKNDC 008835 and 008836). Scale bar $=10 \mu \mathrm{m}$. 

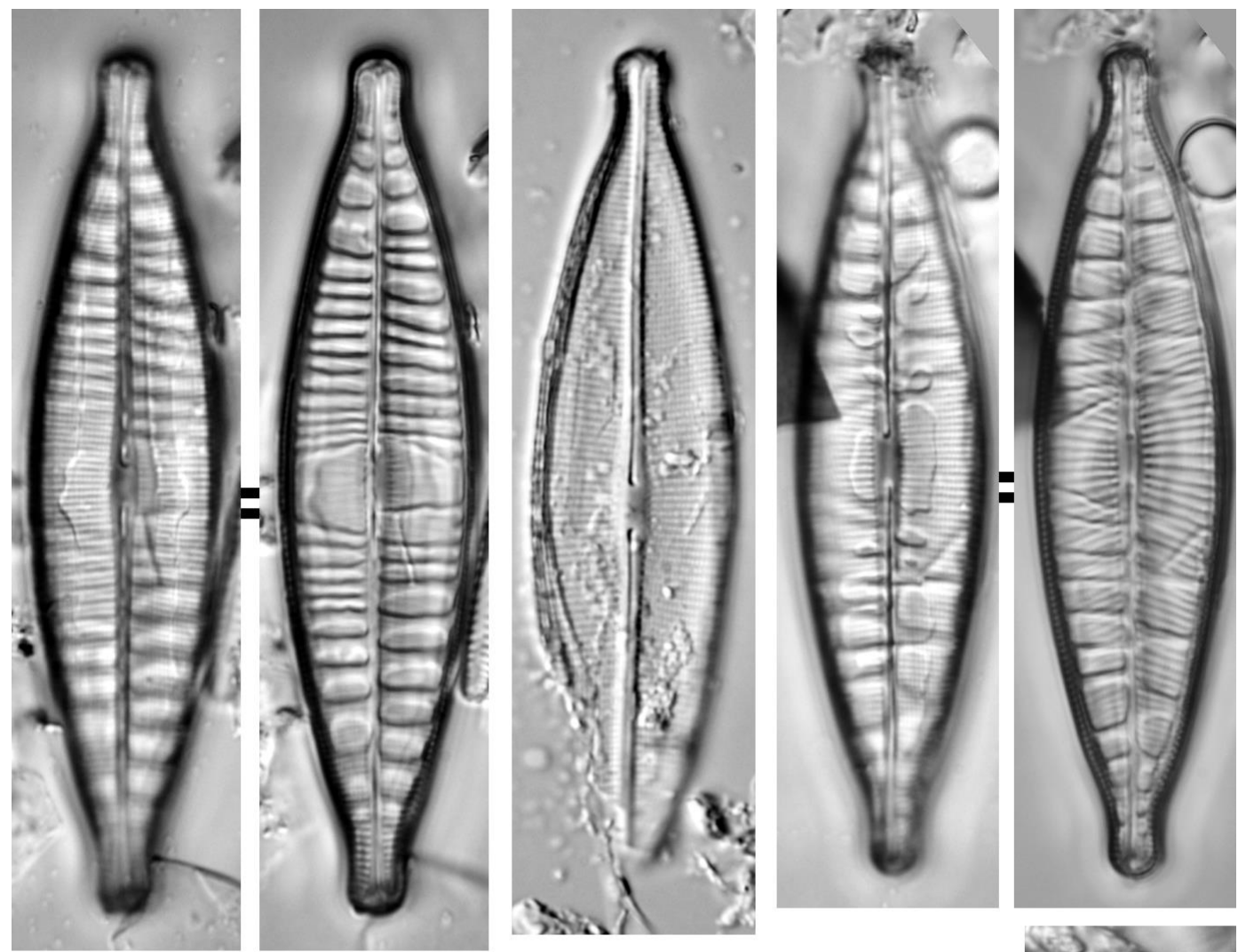

\section{$1-11$}
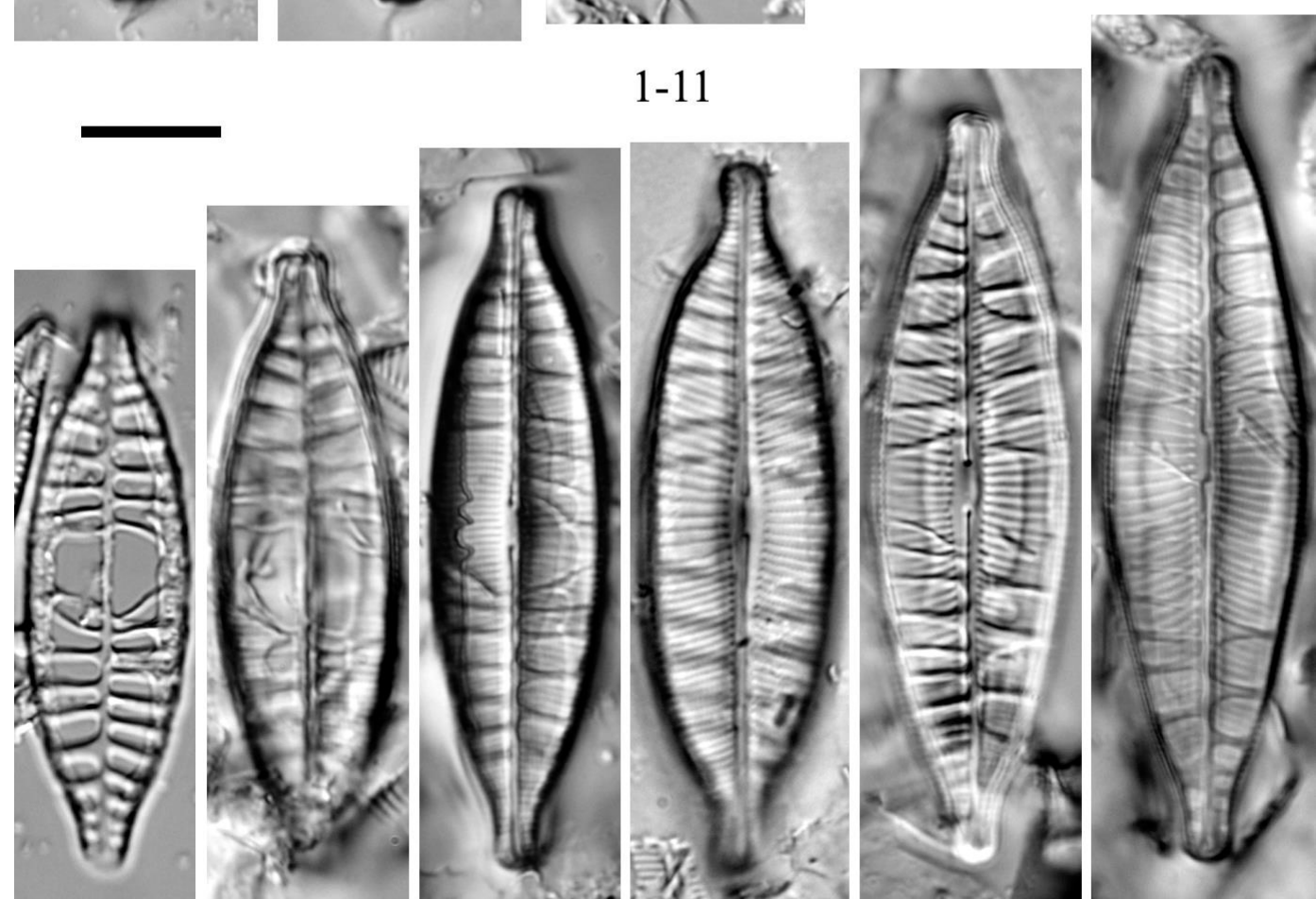

Figure 12: 1-11. LM micrographs of Craticula fumantii Lange-Bertalot, Cavacini, Tagliaventi \& Alfinito. Lake Karanikoličko, Šara Mountain, macrophytes (Slide MKNDC 003084). Scale bar $=10 \mu \mathrm{m}$. 

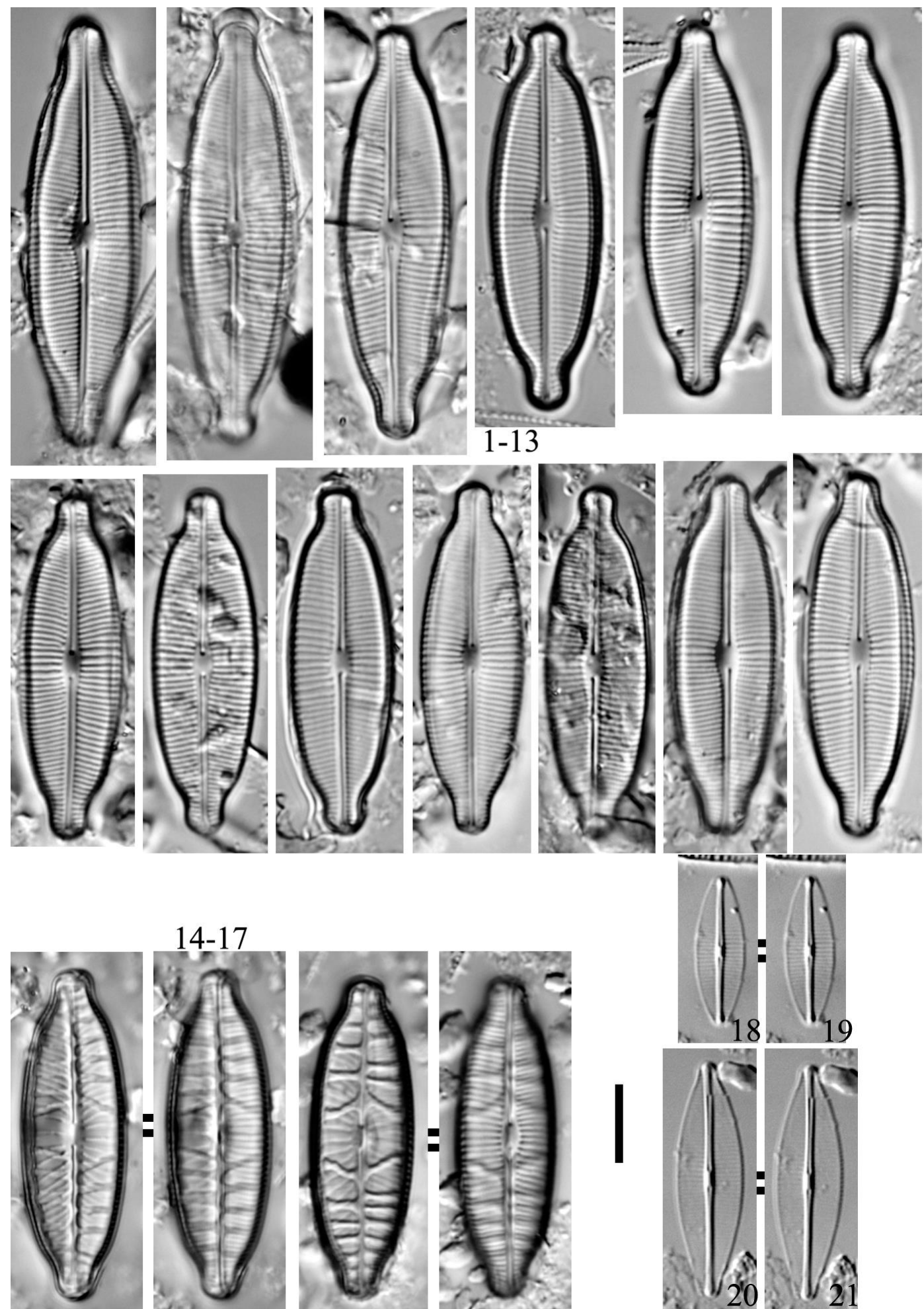

$14-17$
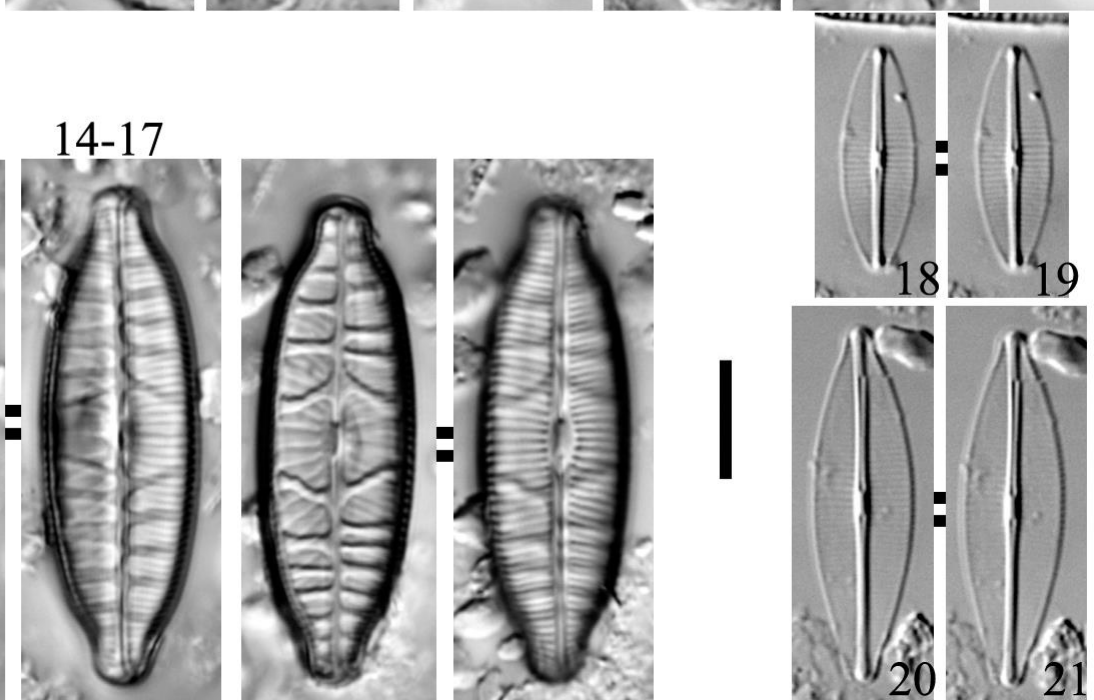

Figure 13: 1-17. LM micrographs of Craticula germainii Lange-Bertalot, Cavacini, Tagliaventi \& Alfinito. Sveti Nikole, near the village of Adzimatovo, pond, mud (Slide MKNDC 008835). 18, 19. LM micrographs of Craticula minusculoides (Hustedt) Lange-Bertalot. Gladno Pole, near Shtip, spring, mud (Slide MKNDC 008838).

20, 21. LM micrographs of Craticula aff. molestiformis (Hustedt) D.G.Mann. The River Bregalnica, before the village of Mačevo, epiphytes on reed (Slide MKNDC 006795). Scale bar $=10 \mu \mathrm{m}$. 

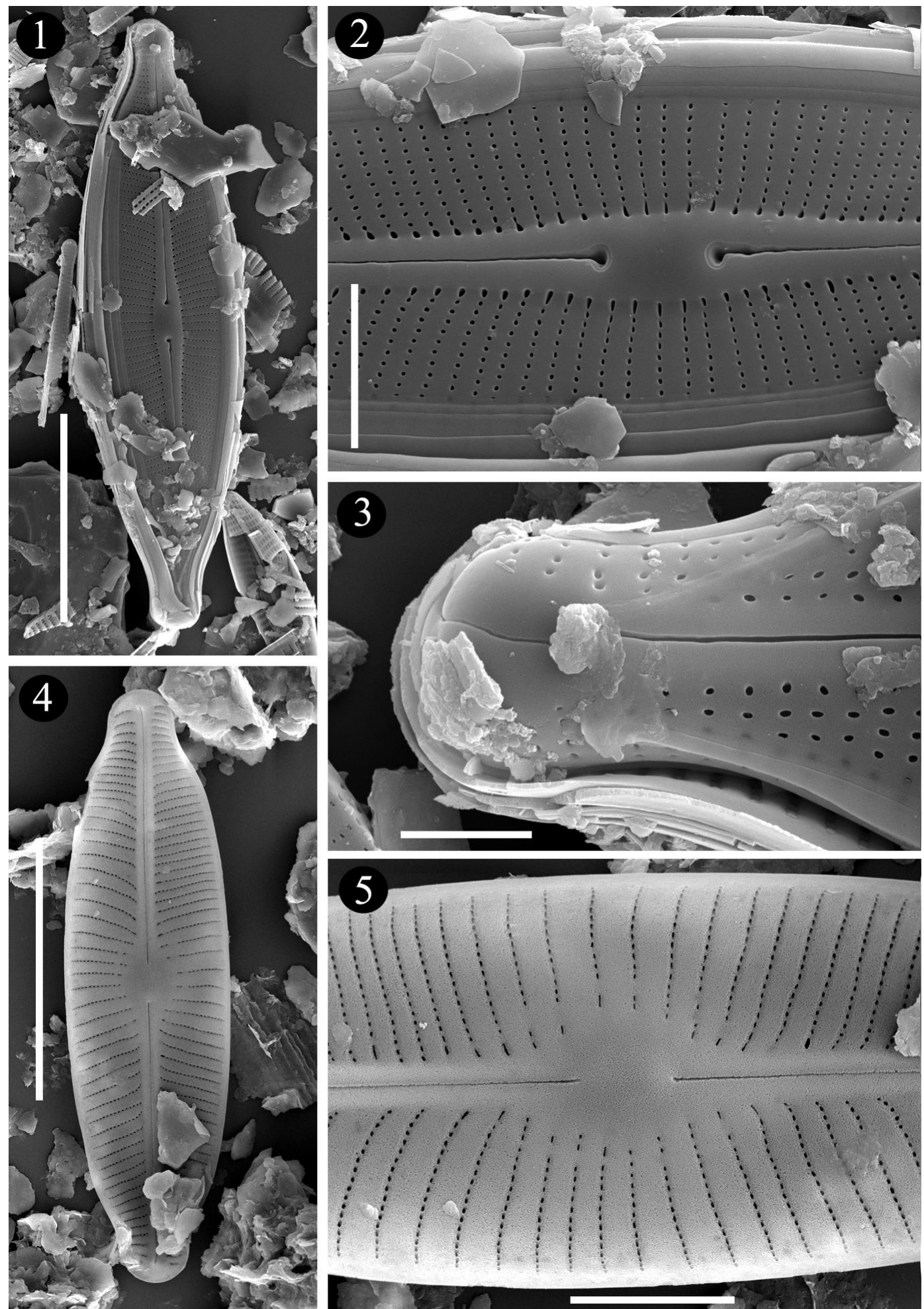

Figure 14: 1-3. Scanning electron micrographs of Craticula fumantii. 1. External view of the whole valve. 2. Detailed view of the mid-valve. The central area is strongly thickened. Proximally raphe branches terminate with large central pores.

3. Detailed view of the valve apex. The raphe fissure is long, curved and continuing on the valve mantle.

4, 5. Scanning electron micrographs of Craticula germainii. 4. Internal view of the whole valve.

5. Detailed view of the mid-valve. Central area is distinct and bordered with more distantly spaced striae. Scale bar $=20 \mu \mathrm{m}(\mathbf{1}, \mathbf{4}), 5 \mu \mathrm{m}(\mathbf{2}, \mathbf{5}), 2 \mu \mathrm{m}(\mathbf{3})$. 

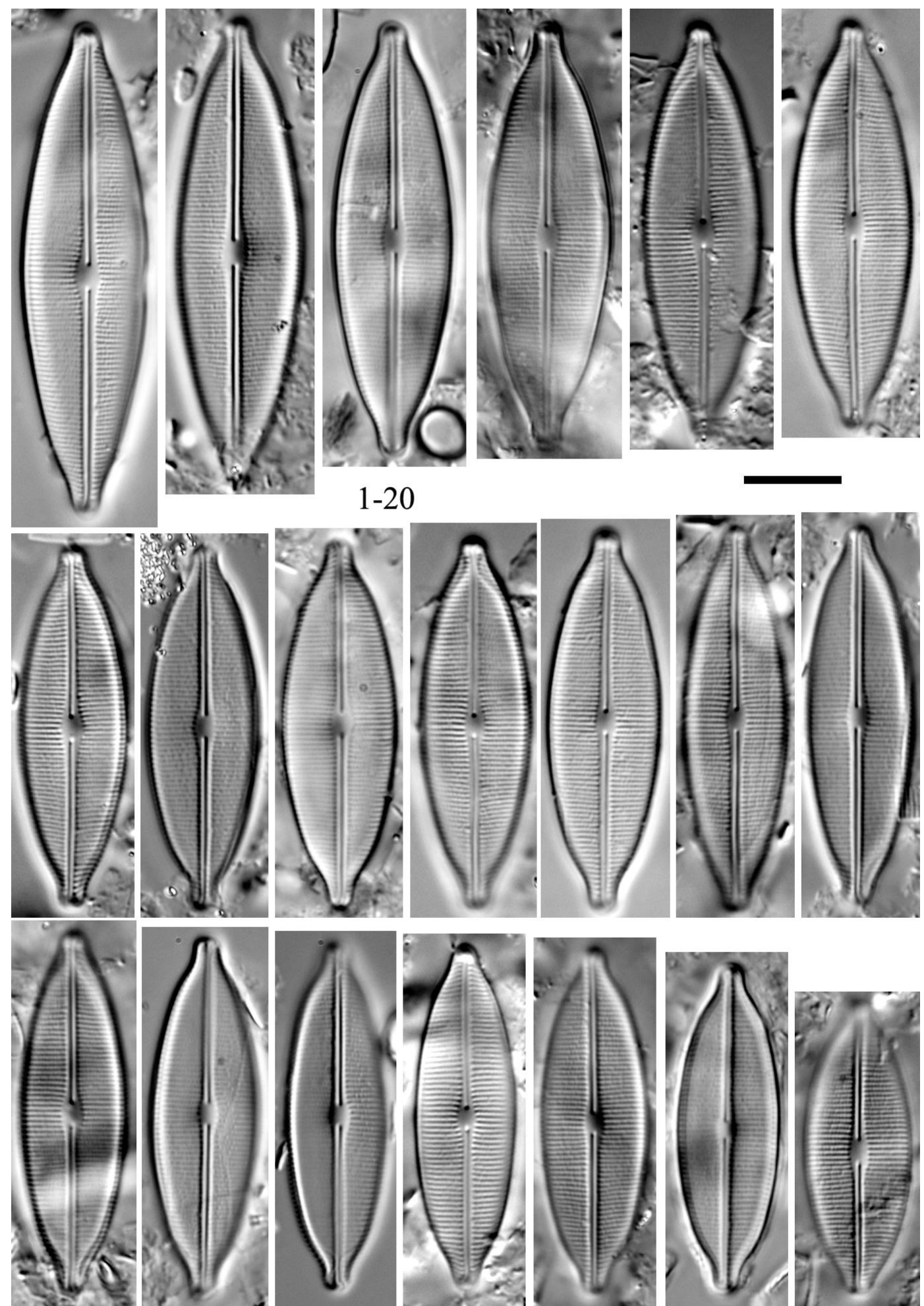

Figure 15: 1-20. LM micrographs of Craticula accomodiformis Lange-Bertalot.

Thermo-mineral spring Negorska Banja, rock scrape (Slide MKNDC PS001035). Scale bar $=10 \mu \mathrm{m}$. 


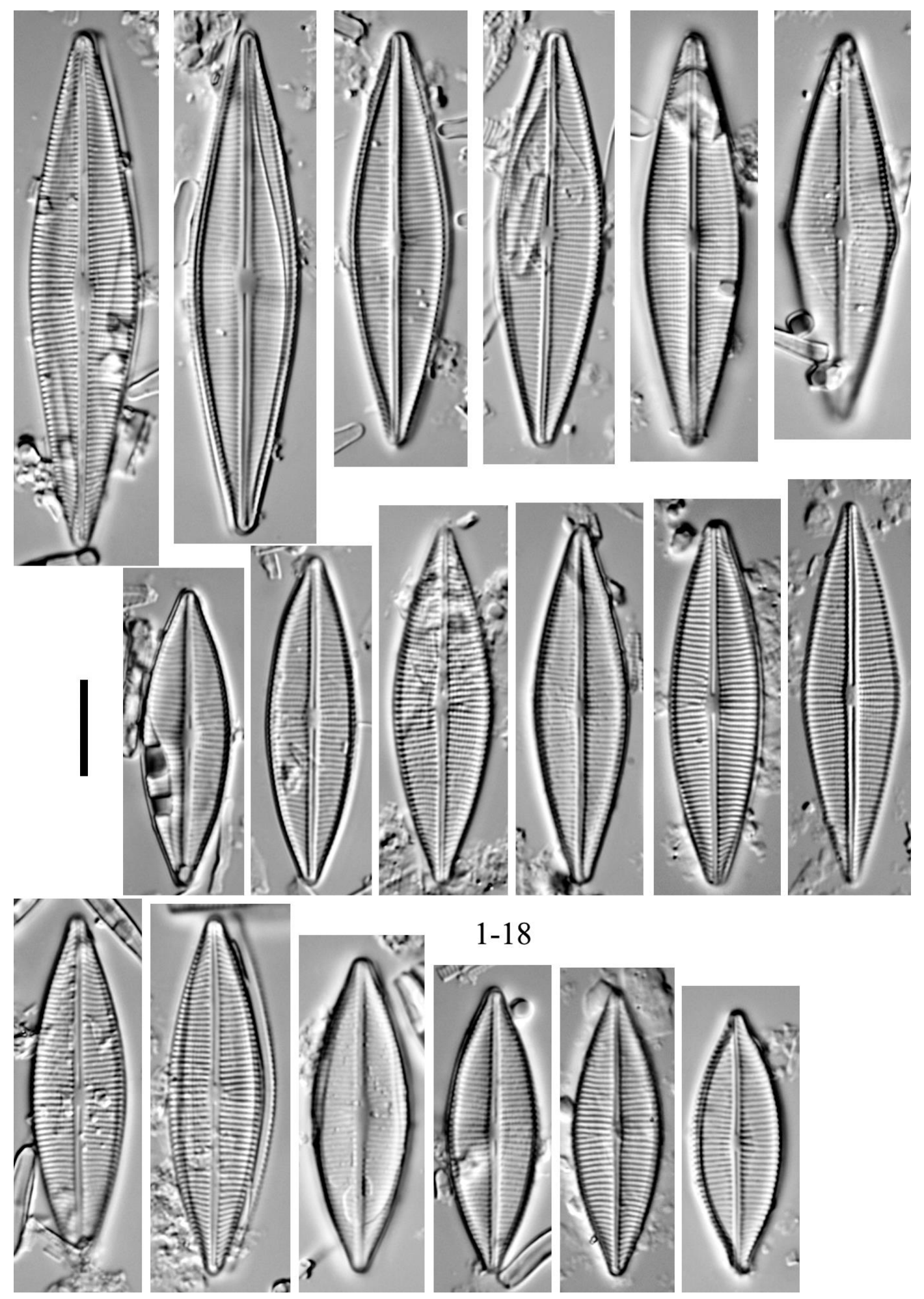

Figure 16: 1-18. LM micrographs of Craticula halophila (Grunow) D.G.Mann. Slan Dol, temporary pond, mud (Slide MKNDC 008873). Scale bar $=10 \mu \mathrm{m}$. 

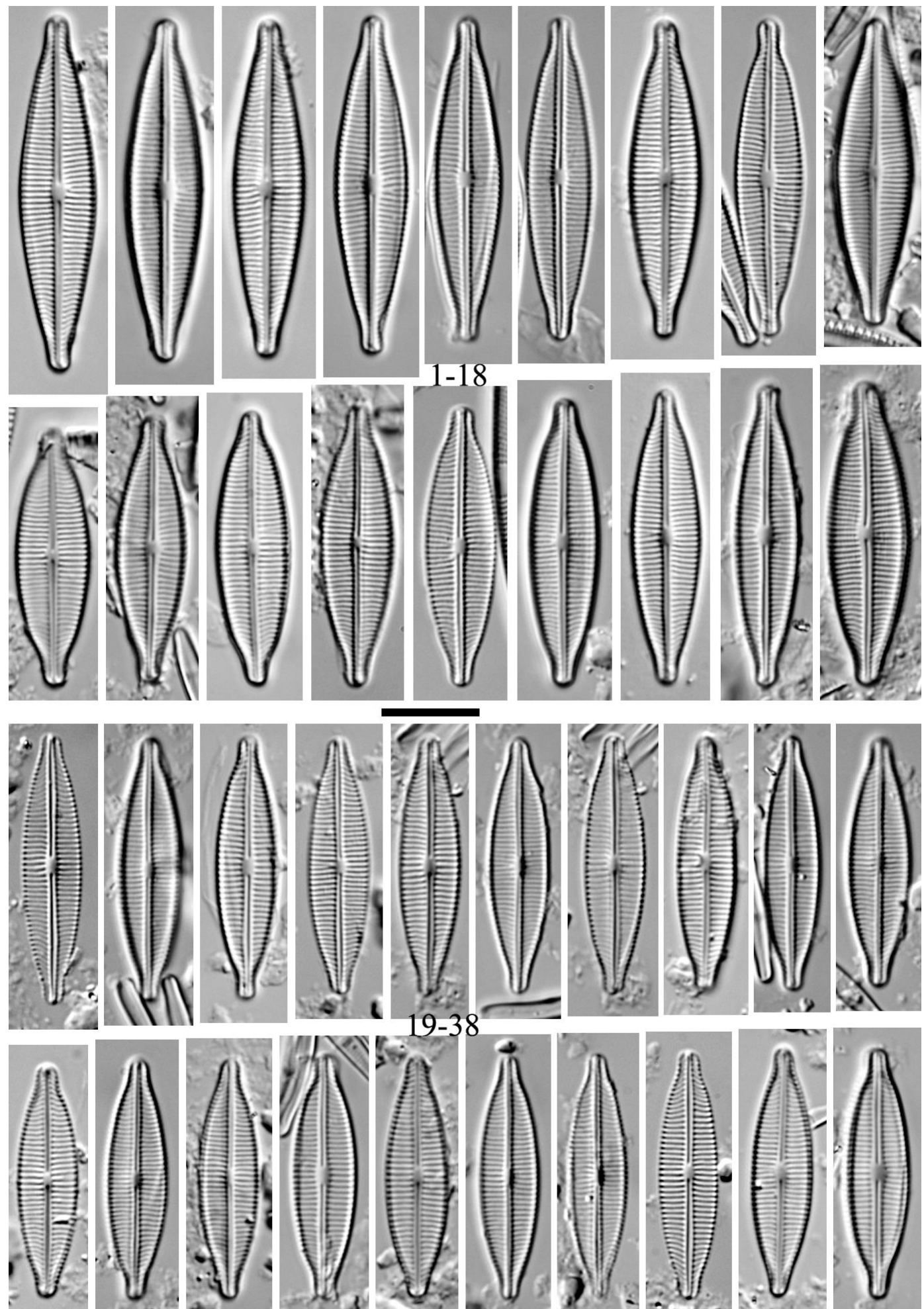

Figure 17: 1-18. LM micrographs of Craticula simplex (Krasske) Levkov comb. nov. MT 1. Mineral spring near the village of Gabrovo, Delchevo, Chara sp. (Slide MKNDC 008858). 19-38. LM micrographs of Craticula simplex Krasske) Levkov comb. nov. MT 2. Slan Dol, pond, macrophytes (Slide MKNDC 008872). Scale bar $=10 \mu \mathrm{m}$. 

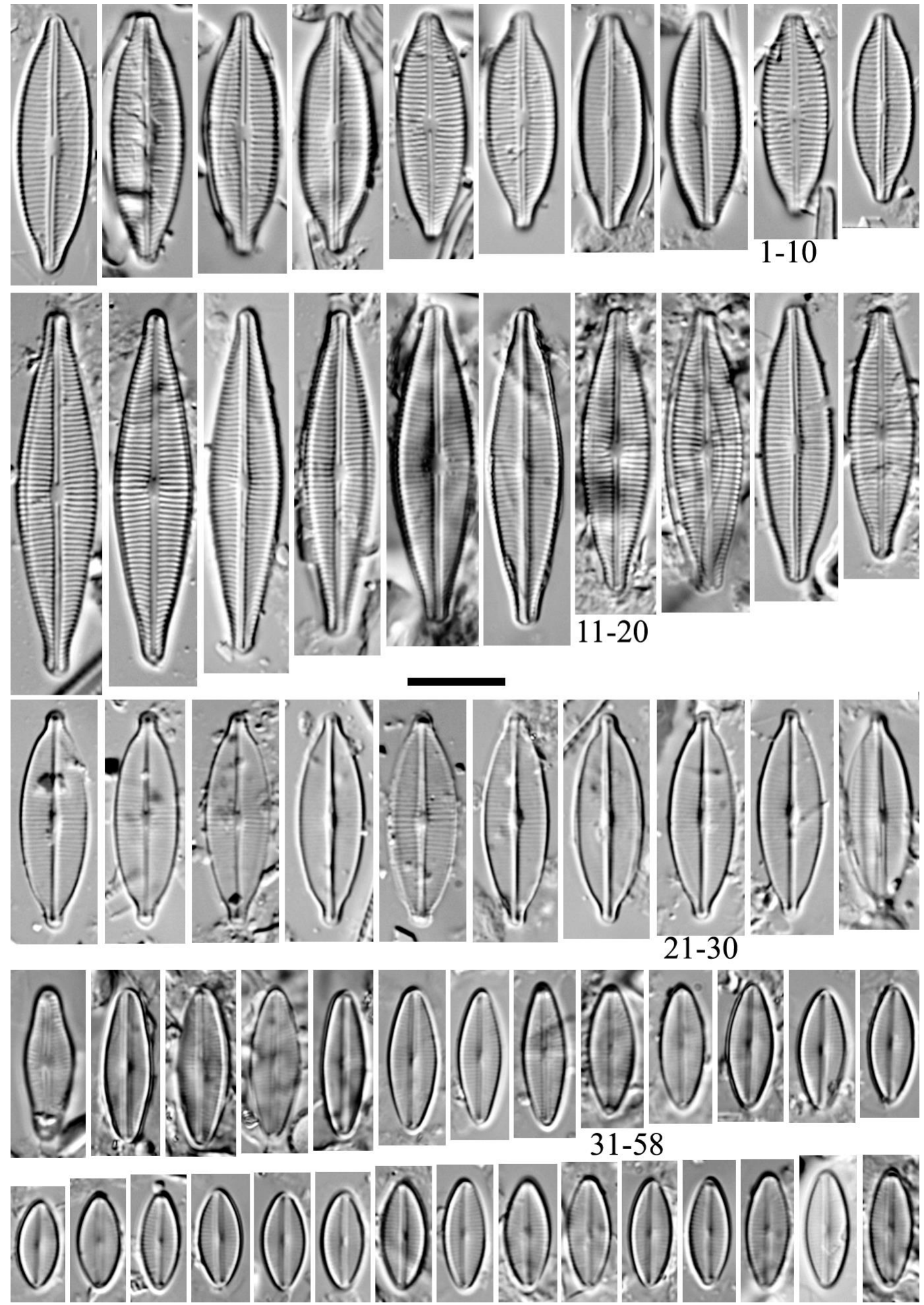

Figure 18: 1-10. LM micrographs of Craticula simplex (Krasske) Levkov comb. nov. MT 3. Slan Dol, pond, mud (Slide MKNDC 008873). 11-20. LM micrographs of Craticula simplex (Krasske) Levkov comb. nov. MT 1. Slan Dol, pond, macrophytes (Slide MKNDC 008872). 21-30. LM micrographs of Craticula accomoda (Hustedt) D.G.Mann. Mining Lake Usje, macrophytes (Slide MKNDC 005603). 31-58. LM micrographs of Craticula molestiformis (Hustedt) Lange-Bertalot. Reservoir Ratevsko, sediment (Slide MKNDC 006967). Scale bar $=10 \mu \mathrm{m}$. 

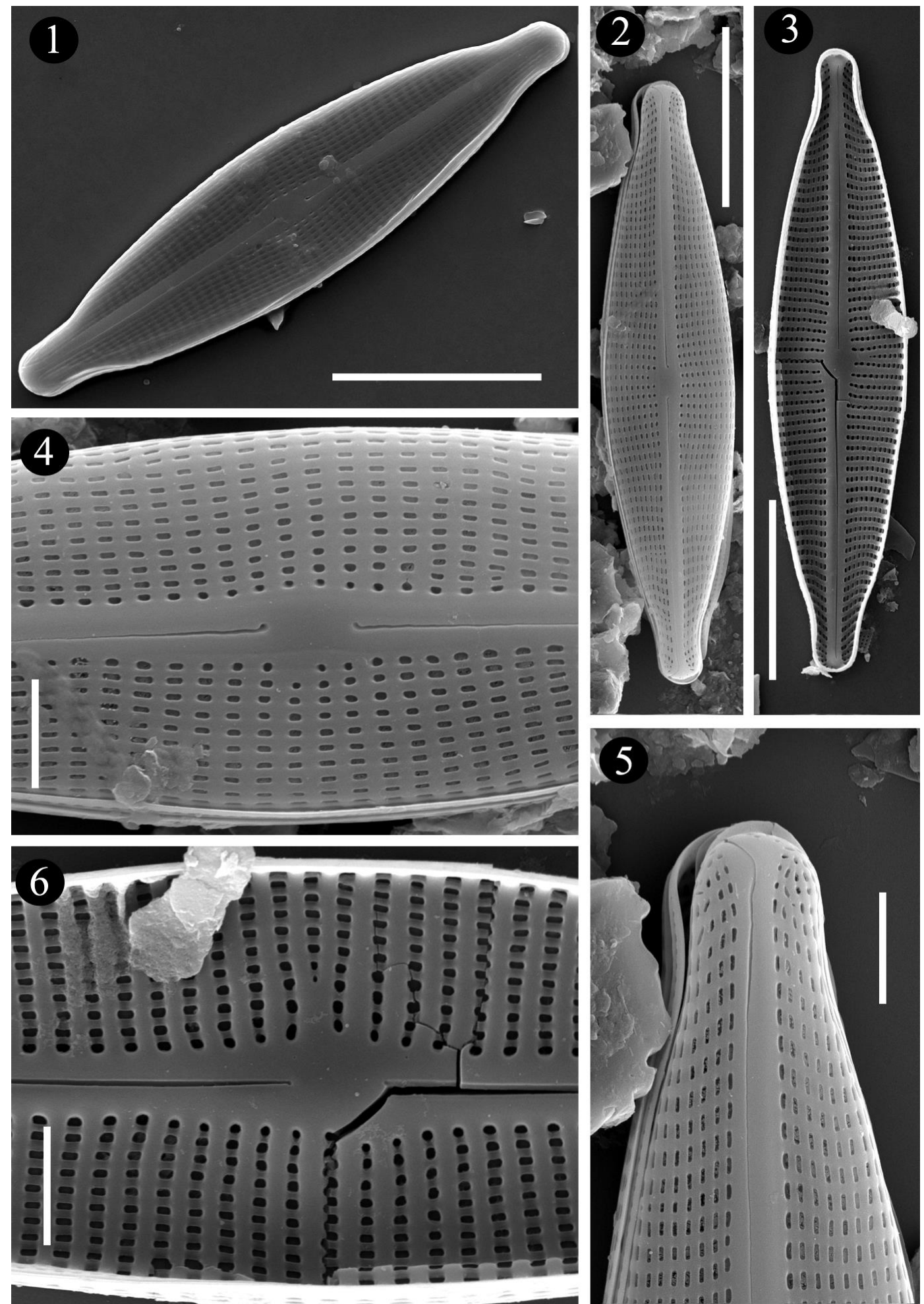

Figure 19: 1-6. Scanning electron micrographs of Craticula simplex. 1, 2. External view of the whole valve. 3. Internal view of the whole valve. Raphe located on strongly thickened sternum. 4. Detailed view of the mid-valve. Areolae in the mid-valve have round foramina near the central area, while distally are longitudinally elongated foramina. Proximal raphe endings slightly unilaterally deflected. 5. Detailed view of the valve apex. Distal raphe fissures long, hooked and continuing on the valve mantle. 6. Internal view of the mid-valve. Proximal raphe endings not expanded.

Scale bar $=10 \mu \mathrm{m}(\mathbf{1}-\mathbf{3}), 2 \mu \mathrm{m}(\mathbf{4}-\mathbf{6})$. 

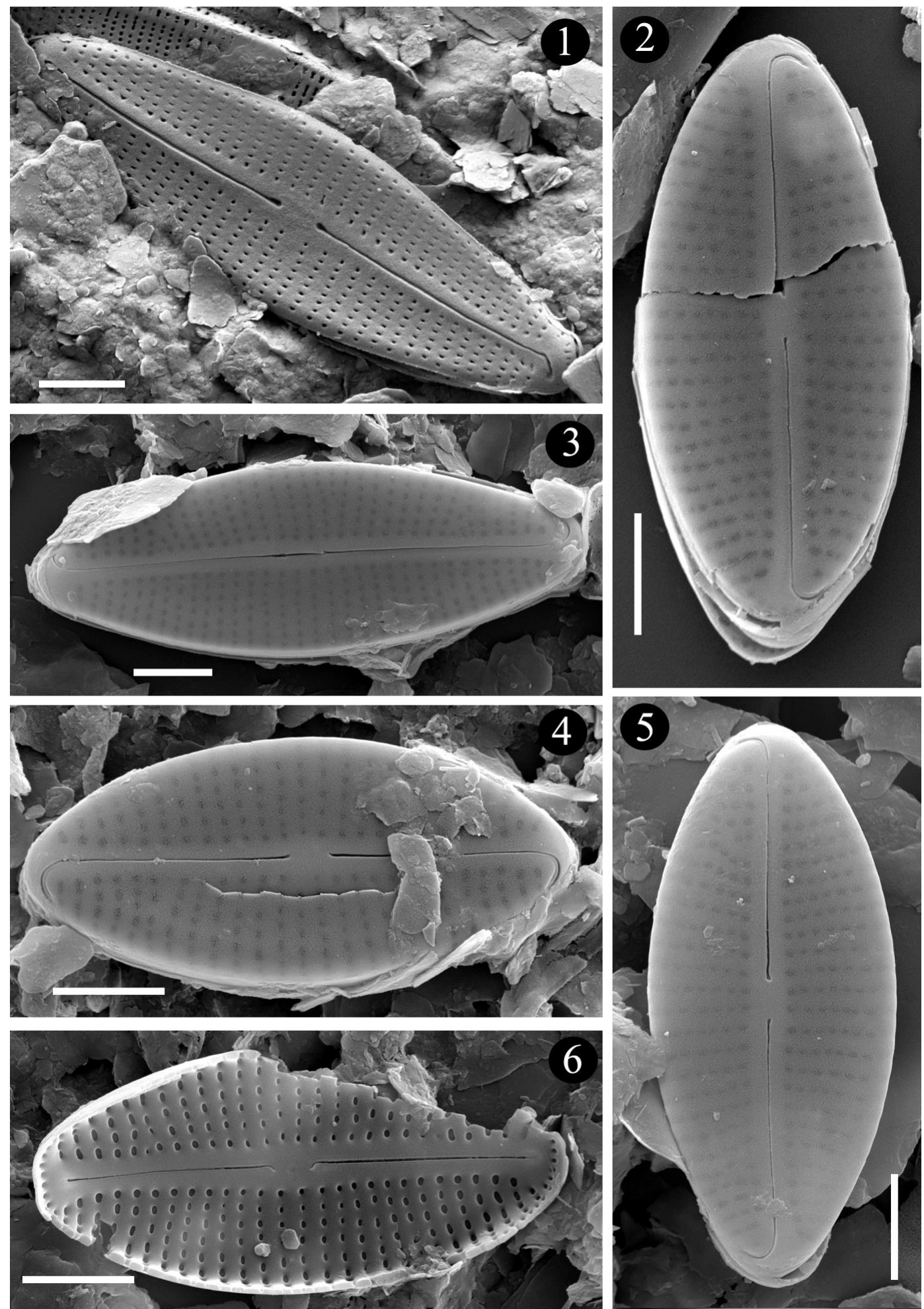

Figure 20: 1. Scanning electron micrograph of Craticula minusculoides. Distally raphe fissures deflected and not continuing on the valve mantle, proximally terminate with small central pores. Areolae around central area and near the raphe with round openings, the rest with small longitudinally orientated openings. 2-6. Scanning electron micrographs of Craticula molestiformis. 2-5. External view of the whole valve. Distally raphe fissures long, hooked and continuing on the valve mantle. Externally, areolae occluded with a fine hymen. 6. Internal valve view. Raphe branches located on the valve surface, without elevated sternum. Areolae occluded with hymen located towards the outer valve surface.

Proximal raphe endings unilaterally deflected. Scale bar $=2 \mu \mathrm{m}(\mathbf{1}-\mathbf{6})$. 

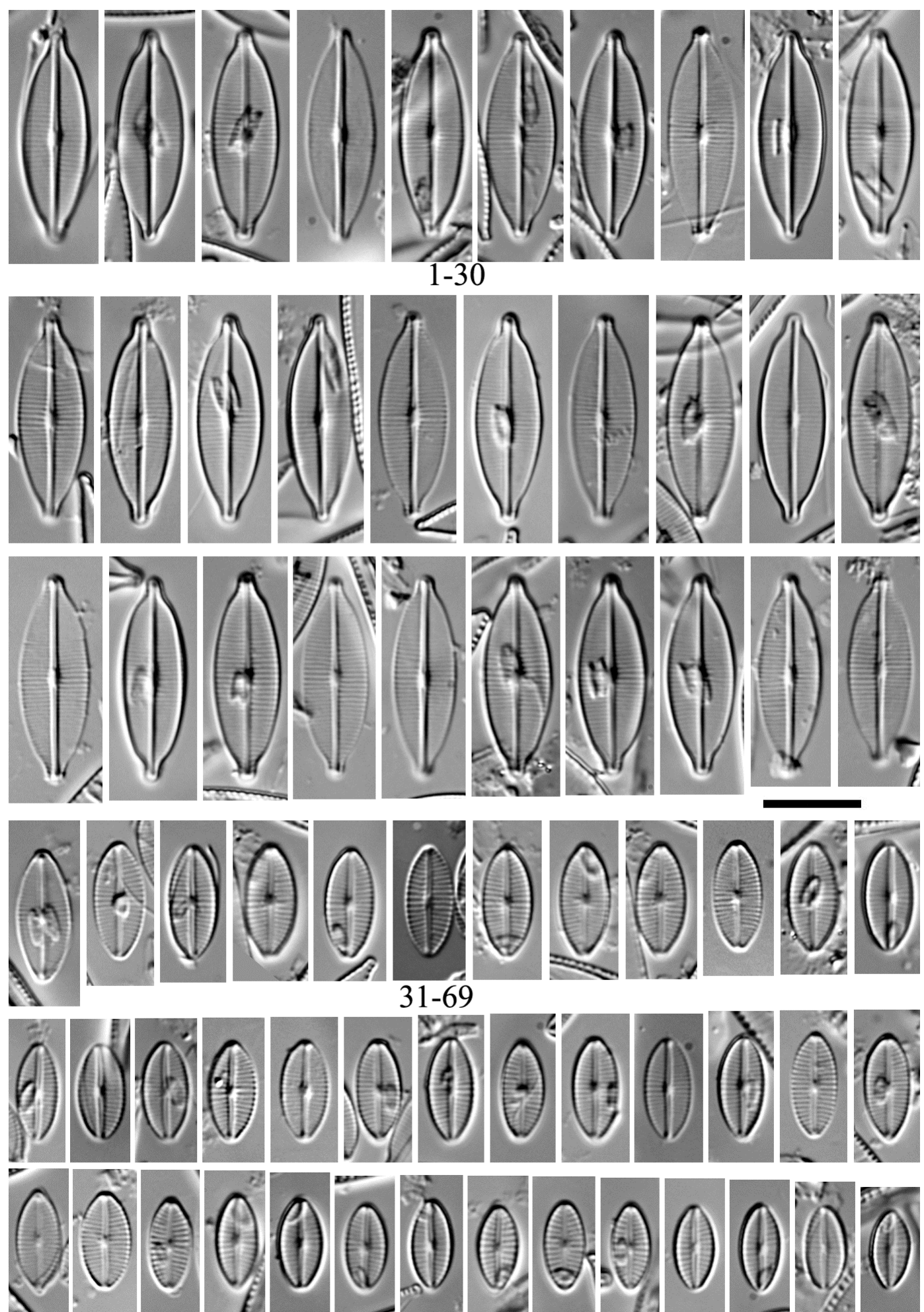

Figure 21: 1-30. LM micrographs of Craticula accomoda (Hustedt) D.G.Mann. The River Vodenišnica, near Monospitovo, rock scrape (Slide MKNDC 008234). 31-69. LM micrographs of Craticula subminuscula (Manguin) C. E. Wetzel \& Ector. The River Vodenišnica, near Monospitovo, rock scrape (Slide MKNDC 008234). Scale bar $=10 \mu \mathrm{m}$. 

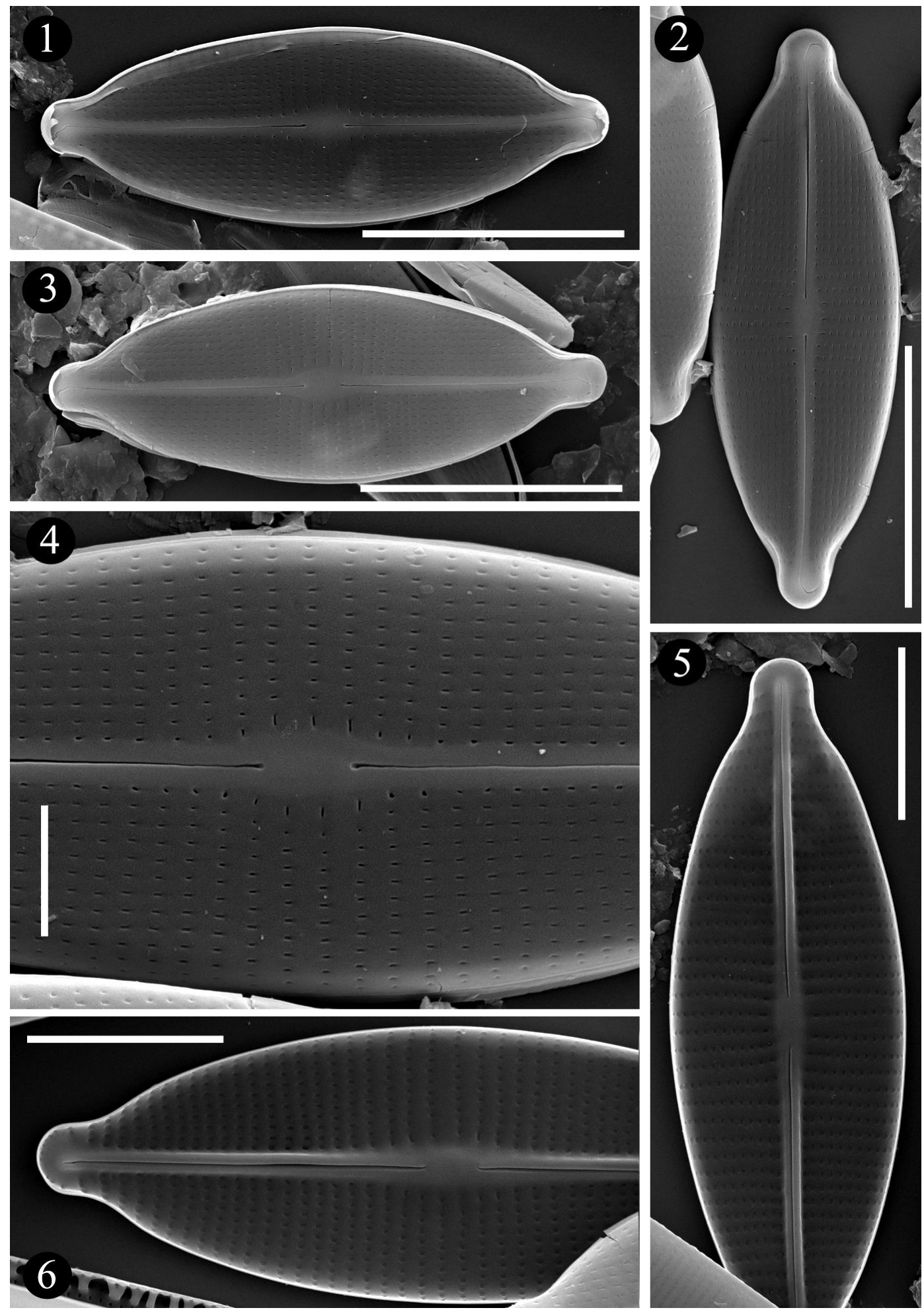

Figure 22: 1-6. Scanning electron micrographs of Craticula accomoda. 1-3. External view of the whole valve.

4. Detailed view of the mid-valve. Areolae around central area with transversally elongated slit-like opening, the rest with longitudinally orientated openings. 5, 6. Internal view. Areolae are occluded by hymen. Raphe located on elevated sternum. Scale bar $=10 \mu \mathrm{m}(\mathbf{1}-\mathbf{3}), 2 \mu \mathrm{m}(\mathbf{4}), 5 \mu \mathrm{m}(\mathbf{5}, \mathbf{6})$. 

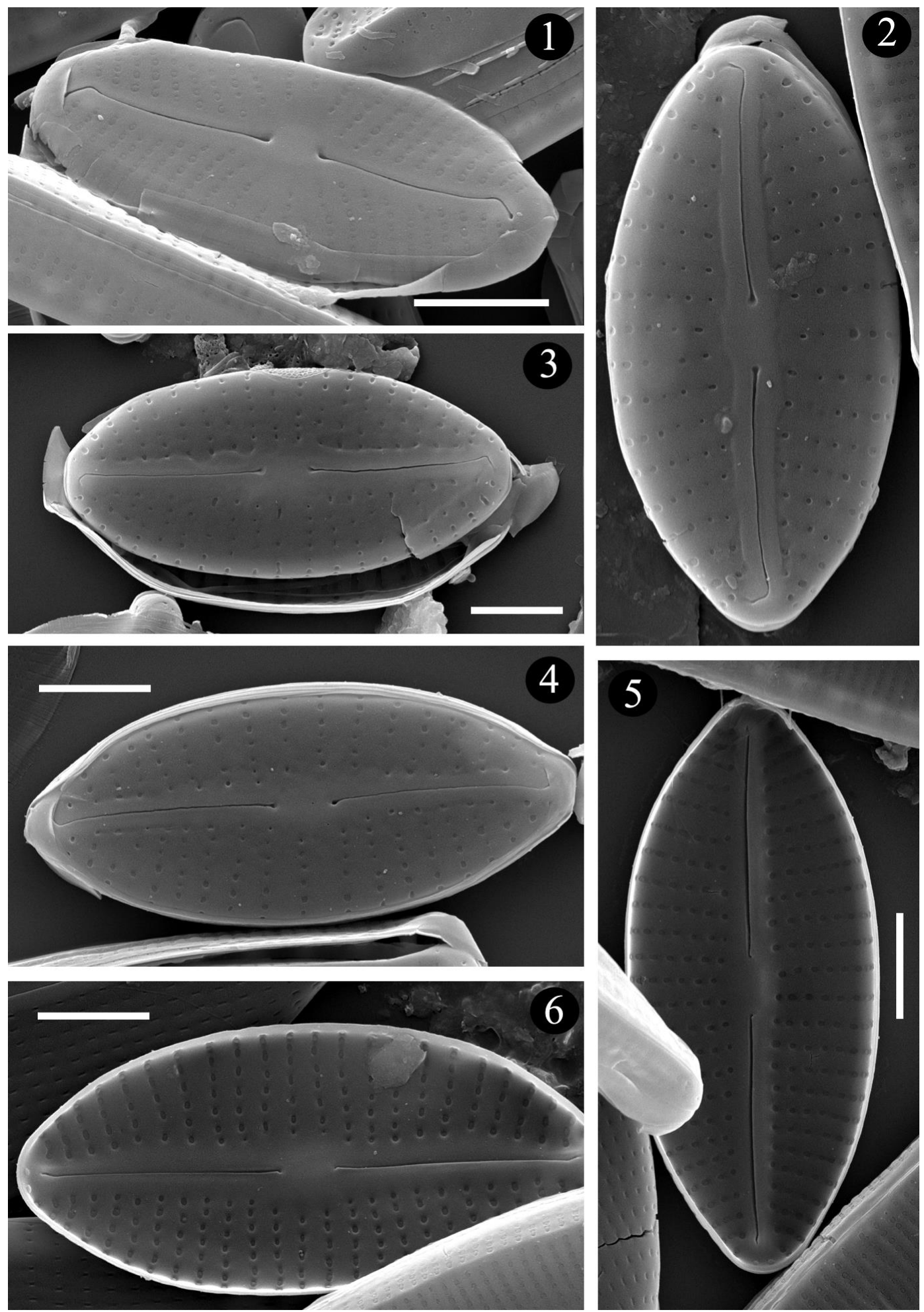

Figure 23: 1-6. Scanning electron micrographs of Craticula subminuscula. 1-4. External view of the whole valve. Distally raphe fissures strongly deflected, not continuing on the valve mantle. Proximally raphe fissures terminate with small central pores, slightly deflected on the same side. Areolae with small, round foramina. 5, 6. Internal view.

Areolae are occluded by hymen. Raphe branches located on the valve surface, without elevated sternum. Scale bar $=2 \mu \mathrm{m}(\mathbf{1}-\mathbf{6})$. 
Acknowledgements. The authors would like to express gratitude to Luc Ector, Luxembourg Institute of Science and Technology (LIST), Environmental Research and Innovation (ERIN) Department for providing valuable references for Craticula taxonomy and ecology. We would also like to express our gratitude to Dr. Bart Van de Vijver, Botanic Garden Meise, Department Bryophyta \& Thallophyta and Paul Hamilton, Research and Collections Division, Canadian Museum of Nature for very helpful comments and discussions during the manuscript preparation. This study was partly supported by the project "Ecological Data Gap Analysis and Ecological Sensitivity Map Development for the Bregalnica River Watershed" that was implemented within the Nature Conservation Programme in Macedonia, financed by the Swiss Agency for Development and Cooperation (SDC); and partly by Alexander von Humboldt Foundation.

\section{REFERENCES}

[1] A. Grunow, Reise der Österreichischen Fregatte Novara um die Erde in den Jahren 1875, 1858, 1859. Botanischer Theil. Band I. Algae. Wien, aus der Kaiserlich-Königlichen Hof- und Staatsdruckerei 1867, pp. 1-104, pls I, Ia, II-XI.

[2] D. G. Mann, A. J. Stickle, The genus Craticula. Diatom Res., 6 (1991), pp. 79-107.

[3] P. T. Cleve, Synopsis of the naviculoid diatoms. Kongl. Svenska Vetensk.-Akad. Handl., 26 (1894), pp 1-194.

[4] F. Hustedt, Die Kieselalgen Deutschland, Österreichs und \& Schweiz unter Berücksichtigung der übrigen Länder Europas sowie der angrezenden Meeresgebiete. In: L. Rabenhorst (ed.), Kryptogamen Flora von Deutschland, Österreich und der Schweiz. 7 (Teil 3, Lief. 1), 1961, pp. 1-160, Figs 1180-1294. Akademische Verlagsgesellschaft m.b.h. Leipzig.

[5] A.-M. M. Schmid, Influence of environmental factors on the development of the valve in diatoms. Protoplasma, 99 (1979), pp. 99-115.

[6] A.-M. M. Schmid, Induction of resting-spores in the pennate diatom Navicula (Craticula) cuspidata by uncoupling of the cell and plastid cycles. Nova Hedwigia Beih., 135 (2009), pp. 85-101.

[7] E. J. Cox, Variation in patterns of valve morphogenesis between representatives of six biraphid diatom genera (Bacillariophyceae). J. Phycol., 35 (1999), pp. 1297-1312.

[8] E. A. Morales, M. Le, The taxonomy of the diatom Lacunicula sardiniensis Lange-Bertalot, Cavacini, Tagliaventi et Alfinito and its relationship with the genus Craticula Grunow (Bacillariophyceae). Proc. Acad. Nat. Sci. Philadelphia, 154 (2005), pp. 155-161.

[9] H. Lange-Bertalot, 85 neue Taxa und über 100 weitere neu definierte Taxa ergänzend zur
Süsswasserflora von Mitteleuropa, Vol. 2/1-4. Biblioth. Diatomol., 27 (1993), pp 1-164.

[10] H. Lange-Bertalot, Navicula sensu stricto. 10 genera separated from Navicula sensu lato. Frustulia. Diatoms of Europe, 2 (2001), pp 1-526.

[11] H. Lange-Bertalot, P. Cavacini, N. Tagliaventi, S. Alfinito, Diatoms of Sardinia. Rare species and 76 new species in rock pools and other ephemeral waters. Iconogr. Diatomol., 12 (2003), pp. 1-438.

[12] E. A. Morales, C. E. Wetzel, S. F. Rivera, M. H. Novais, L. Hoffmann, L. Ector, Craticula strelnikoviana sp. nov. and Craticula guaykuruorum sp. nov. (Bacillariophyta) from South American saline lakes. Nova Hedwigia Beih., 143 (2014), pp. 223-237.

[13] U. Rumrich, H. Lange-Bertalot, M. Rumrich, Diatoms of the Andes. From Venezuela to Patagonia/Tierra del Fuego and two additional contributions. Iconogr. Diatomol., 9 (2000), pp. 1-673.

[14] B. Van de Vijver, M. Sterken, W. Vyverman, G. Mataloni, L. Nedbalova, K. Kopalova, J. Elster, E. Verleyen, K. Sabbe, Four new non-marine diatom taxa from the Subantarctic and Antarctic regions. Diatom Res., 25 (2010), pp. 431-443.

[15] K. Sabbe, E. Verleyen, D. A. Hodgson, K. Vanhoutte, W. Vyverman, Benthic diatom flora of freshwater and saline lakes in the Larsemann Hills and Rauer Islands, East-Antarctica. Antarc. Sci., 15 (2003), pp. 227-248.

[16] B. Schröder, Phytoplankton von Seen aus Mazedonien. Sitzungsb. der Akad. d. Wiss. in Wien, Mathem.-naturw. Kl. Abt. I, 130 (1921), pp 147-186.

[17] F. Hustedt, Diatomeen aus Seen und Quellgebieten der Balkan-Halbinsel. Arch. Hydrobiol., 40 (1945), pp. 867-973, 12 pls.

[18] E. Manguin, Contribution à la connaissance des diatomées d'eau douce des Açores. Travaux Algologiques, Sér. 1. Muséum National d'Histoire Naturelle, Laboratoire de Cryptogamie, 2 (1942), pp. 115-160, 4 pls.

[19] K. Krammer, H. Lange-Bertalot, Bacillariophyceae, 1. In: H. Ettl, J. Gerloff, H. Heynig, D. Mollenhauer (Eds): Süßwasserflora von Mitteleuropa. Bd. 2/1. Fischer, Stuttgart - New York, 1986.

[20] P. Stojanov, Algal flora in the Lake Doiran periphyton. God. Zbor. Biol., 36 (1983), pp. 95-107.

[21] S. Krstic, Lj. Melovski, Z. Levkov, P. Stojanovski, Complex investigations on the river Vardar. II. The most polluted sites in the first 3 months. Ekol. Zast. Zivot. Sred., 2 (1994), pp. 13-29.

[22] Z. Levkov, Amphora sensu lato. Diatoms of Europe, 5 (2009), pp. 1-916.

[23] A. Pavlov, Z. Levkov, Diversity and distribution of Eunotia Ehrenberg in Macedonia. Phytotaxa, 86 (2013), pp. 1-117. 
[24] A. Pavlov, Z. Levkov, D. M. Williams, M. B. Edlund, Observations on Hippodonta (Bacillariophyceae) in selected ancient lakes. Phytotaxa, 90 (2013), pp. 1-53.

[25] E. Jovanovska, T. Nakov, Z. Levkov, Observations of the genus Diploneis (Ehrenberg) Cleve from Lake Ohrid, Macedonia. Diatom Res., 28 (2013), pp. 237-262.

[26] Z. Levkov, D. Metzeltin, A. Pavlov, Luticola and Luticolopsis. Diatoms of Europe, 7 (2013), pp. 1697.

[27] I. Jüttner, D. M. Williams, Z. Levkov, E. Falasco, M. Battegazzore, M. Cantonati, B. Van de Vijver, C Angele, L. Ector, Reinvestigation of the type material for Odontidium hyemale (Roth) Kützing and related species, with description of four new species in the genus Odontidium (Fragilariaceae, Bacillariophyta). Phytotaxa, 234 (2015), pp. 1-36.

[28] A. Pavlov, E. Jovanovska, C. E. Wetzel, L. Ector, Z. Levkov, Freshwater Mastogloia (Bacillariophyceae) taxa from Macedonia, with a description of the epizoic $M$. sterijovskii sp. nov. Diatom Res., 31 (2016), pp. 1-29.

[29] Z. Levkov, D. Mitić-Kopanja, E. Reichardt, The diatom genus Gomphonema from the Republic of Macedonia. Diatoms of Europe, 8 (2016), pp. 1-552.

[30] J. Frenguelli, Diatomeas fósiles del Prebelgranense de Miramar (Contribucion IV). Bol. Acad. Nac. Cienc., 29 (1926), pp. 5-89, pls I-IX.

[31] F. T. Kützing, Synopsis Diatomacearum oder Versuch einer systematischen Zusammenstellung der Diatomeen. Linnaea, 8 (1833), pp. 529-620, pls XIII-XIX.

[32] F. T. Kützing, Die Kieselschaligen. Bacillarien oder Diatomeen. Nordhausen. 152 pp., 30 pls., 1844.

[33] H. Lange-Bertalot, D. Metzeltin, Indicators of oligotrophy -800 taxa representative of three ecologically distinct lake types, Carbonate buffered - Oligodystrophic-Weakly buffered soft water. Iconogr. Diatomol., 2 (1996), pp. 1-390.

[34] L. Bahls, New diatoms (Bacillariophyta) from western North America. Phytotaxa, 82 (2013), pp. $7-28$.

[35] C. G. Ehrenberg, Verbreitung und Einflufs des mikroskopischen Lebens in Süd-und NordAmerika. Abh. Königl. Akad. Wiss. Berlin, 1841 (1843), pp. 291-445, 4 pls.

[36] P. T. Cleve, Synopsis of the Naviculoid Diatoms, Part I. Kongl. Svenska Vetensk. Acad. Handl., 26 (1894), pp. 1-194, 5 pls.

[37] E. Reichardt, Neue Diatomeen (Bacillariophyceae) aus dem Gebiet der Stadt Treuchtlingen. Ber. Bayer. Bot. Ges., 82 (2012), pp. 19-32.

[38] Z. Levkov, S. Krstic, T. Nakov, Lj. Melovski, Diatom assemblages on Shara and Nidze Mountains, Macedonia. Nova Hedwigia, 81 (2005), pp 501-538.
[39] P. Stojanov, Diatoms from aquatic ecosystems in the National Park "Pelister". Biosistematika, 8 (1982), pp 1-17.

[40] P. Stojanov, Diatom microflora of some aquatic ecosystems on Jakupica Mountain, Macedonia. God. Zbor. Biol., 35 (1982), pp. 115-129.

[41] P. Stojanov, Diatom microflora in some thermal springs in Macedonia, Yugoslavia. God. Zbor. Biol., 35 (1982), pp. 175-182.

[42] H. Van Heurck, Synopsis des Diatomées de Belgique. Texte. (1885), Martin Brouwers \& Co., Anvers. Pp. 1-235.

[43] G. Krasske, Die Bacillariaceen-Vegetation Niederhessens. Abh. Ber Vereins Naturk. Kassel, 56 (1925), pp. 1-119, 2 pls.

[44] F. Hustedt, Bacillariophyta (Diatomeae). In: A. Pascher (ed.), Die Süsswasser-Flora Mitteleuropas. Gustav Fischer, Jena. Zweite Auflage. Heft 10.(1930), 466 pp., 875 figs.

[45] F. Hustedt, Neue und wenig bekannte Diatomeen. VI. Ber. Deutsch. Bot. Ges., 67 (1954), pp 269280.

[46] W.-K. Kusber, C. Cocquyt, Craticula elkab (O. Müller ex O. Müller) Lange-Bertalot, Kusber \& Cocquyt, comb. nov. - typification and observations based on African sediment core material. Diatom Res., 22 (2007), pp. 117-126.

[47] F. Hustedt, Die Diatomeenflora norddeutscher Seen mit besonderer Berücksichtigung des holsteinischen Seengebiets, V-VII. Seen in Mecklenburg, Lauenburg und Nordostdeutschland. Arch. Hydrobiol., 43 (1950), pp. 329-458.

[48] F. Hustedt, Süsswasser-Diatomeen aus dem Albert-Nationalpark in Belgisch-Kongo. Exploration du Parc National Albert, Mission H. Damas (1935-1936), Rapp. Inst. Parcs Natx. Congo Belge, 8 (1949), pp. 1-199, 16 pls.

[49] G. Moser, H. Lange-Bertalot, D. Metzeltin, Insel der Endemiten Geobotanisches Phänomen Neukaledonien (Island of endemics New Caledonia - a geobotanical phenomenon). Biblioth. Diatomol., 38 (1998), pp. 1-464.

[50] W. Schiller, H. Lange-Bertalot, Eolimna martinii n.gen., n.sp. (Bacillariophyceae) aus dem UnterOligozan von Sieblos/Rhon im Vergleich mit ahnlichen rezenten Taxa. Paläontol. Z., 71 (1997), pp. 163-172.

[51] C. E. Wetzel, L. Ector, B. Van de Vijver, P. Compère, D. G. Mann, Morphology, typification and critical analysis of some ecologically important small naviculoid species (Bacillariophyta). Fottea, 15 (2015), pp. 203-234.

[52] Z. Levkov, S. Krstic, D. Metzeltin, T. Nakov, Diatoms of Lakes Prespa and Ohrid. About 500 taxa from ancient lake system. Iconogr. Diatomol., 16 (2007), pp. 1-603. 


\section{ВИДОВИ ОД РОДОТ CRATICULA GRUNOW (BACILLARIOPHYCEAE) ВO МАКЕДОНИЈА}

\section{Златко Левков, Славица Тофиловска, Данијела Митиќ-Копања}

Институт за биологија, Природно-математички факултет, „Св. Кирил и Методиј“, Скопје, Република Македонија

Видовите од родот Craticula ce широко распространети во Европа и главно се сретнуваат во бракични, солени до силно загадени води. Некои од видовите се сметаат и за едни од најтолерантните кон загадување. Во поново време се спроведени детални истражувања на видовите од родот Craticula. Во рамките на оваа студија се регистрирани вкупно 15 вида. Кај еден од видовите (Craticula simplex) е утврдено постоење на три различни морфотипови, кои можат да се разликуваат според големината и формата на валвата. Craticula cuspidata и $C$. ambigua се видови кои беа најчесто забележани и тоа на различни станишта, додека видовите $C$. halophila, $C$. germainii и $C$. fumantii беа регистрирани само на едно станиште. Највисока видова разновидност на Craticula беше забележана во непостојани бари на халоморфни почви и минерални извори во Источна Македонија.

Клучни зборови: Craticula; дијатомеи; диверзитет; Македонија 
